Katarzyna Kowal

Akademia im. Jana Długosza w Częstochowie

\title{
Między ziemią a niebem... Doświadczanie własnej cielesności przez osoby praktykujące podwieszanie ciała - studium socjologiczne
}

DOI: http://dx.doi.org/10.18778/1733-8069.14.2.04

Abstrakt Celem artykułu jest analiza doświadczania ciała osoby podwieszanej za skórę na hakach przy przyjęciu perspektywy podmiotu jako jednostki ucieleśnionej. Empiryczną podstawę tekstu stanowią autorskie badania socjologiczne przeprowadzone w grupie 30 osób praktykujących podwieszanie ciała, których dobór miał charakter celowy, a określał go co najmniej dwukrotny udział $\mathrm{w}$ tej praktyce cielesnej. Zbieranie i analiza materiału badawczego zostało podporządkowane procedurom metodologii teorii ugruntowanej, w ramach której odwołano się do techniki wywiadu swobodnego ukierunkowanego. Jako że praktyka podwieszania ciała odbywa się według określonego porządku, analiza materiału empirycznego przybrała postać omówienia doświadczania ciała na jej kolejnych sześciu etapach, z których cztery odnoszą się ściśle do samego aktu podwieszenia ciała, a dwa ostatnie dotyczą doświadczeń cielesnych już po jego zakończeniu. W praktykowaniu podwieszania ciała na hakach za skórę ciało ludzkie jest doświadczane przede wszystkim jako źródło przyjemności, której osiągnięcie wyznaczone jest uprzednim doświadczeniem go jako źródła bólu. Ból jest tu doznaniem nieodzownym, bo wyznacza dynamikę tej praktyki cielesnej. Podwieszane ciało jest również traktowane jako obiekt własności, nad którym badani w różnym zakresie roztaczają swoją kontrolę, miejsce kontaktu ze swoim ,ja", narzędzie ekspresji i komunikacji czy wreszcie obiekt troski estetycznej i higienicznej. Analiza doświadczania podwieszanego ciała została przeprowadzona z uwzględnieniem fenomenologicznej perspektywy traktowania ciała jako obiektu fizycznego, który jest ciałem żywym, odczuwającym i emocjonalnym.

Słowa kluczowe ciało, cielesność, doświadczanie własnego ciała, fenomenologia, podwieszanie ciała, modyfikacje ciała

\section{Podwieszanie ciała jako body play}

Podwieszanie ciała współcześnie jest uznawane za jedną z praktyk body play („zabawy z ciałem”), która została zainicjowana i spopularyzowana przez wywodzący się ze Stanów Zjednoczonych ruch Modern Primitives („,współczesnych prymitywistów”) Początki tego powstałego w Californii subkulturowego ruchu ulokowanego na skrzyżowaniu scen tatuażu, piercingu i sadomasochizmu sięgają lat sie-

Katarzyna Kowal, doktor nauk humanistycznych w zakresie socjologii, obecnie zatrudniona na stanowisku adiunkta w Zakładzie Socjologii Akademii im. Jana Długosza w Częstochowie. Jej główne zainteresowania naukowe koncentrują się wokół socjomedycznego nurtu badawczego zdefiniowanego przez Roberta Strausa jako "socjologia w medycynie” (sociology in medicine) oraz tego nurtu socjologii ciała, który nazywany jest socjologią ucieleśnienia (sociology of embodiment). W swojej pracy naukowo-badawczej konsekwentnie korzysta ze strategii badań jakościowych, w realizacji których odwołuje się do metodologii teorii ugruntowanej, analiz biograficznych i socjologii wizualnej. Autorka książki Między altruizmem a egoizmem.

demdziesiątych ubiegłego stulecia (Klesse 2000: 15). Za jego ojca uznawany jest Fakir Musafar przedstawiający się jako szaman, artysta, mistrz piercingu i modyfikator ciała (zob. szerzej Ambrosia, Lanza 1990: 106-117). To, co od samego początku określało neoprymitywistów, to mocne nawiązania do założeń body art, zgodnie z którymi ciało ludzkie zostało uznane za obszar działań twórczych i tym samym istotny nośnik treści. Zgodnie z definicją przedstawioną przez Musafara w utworzonym przez niego czasopiśmie „Body Play and Modern Primitives Quarterly" body play należy rozumieć jako „celowe, rytualne modyfikacje ciała ludzkiego. Jest to głęboko zakorzenione, uniwersalne pragnienie, które przekracza czasowe i kulturowe granice" (BPandMPQ 1[1]: 3 za Klesse 2000: 15-16).

Zainspirowani rytuałami kultur plemiennych współcześni prymitywiści traktują modyfikacje ciała jako te, które mają umożliwić im przekroczenie
Spoteczno-kulturowe uwarunkowania przeszczepów rodzinnych (Toruń 2011) oraz wielu artykułów naukowych i projektów badawczych z pogranicza socjologii, medycyny i etyki. Pełni funkcję sekretarza Sekcji Socjologii Zdrowia i Medycyny Polskiego Towarzystwa Socjologicznego.

\section{Adres kontaktowy:}

Zakład Socjologii

Instytut Nauk Społecznych i Bezpieczeństwa Wydział Filologiczno-Historyczny

Akademia im. Jana Długosza

ul. D. Zbierskiego 2/4, 42-218 Częstochowa

e-mail: k.kowal@ajd.czest.pl 
do tradycji danej społeczności plemiennej oraz pozostaje zharmonizowany z konturami anatomicznymi ciała ludzkiego. Innymi bardziej radykalnymi modyfikacjami współczesnych prymitywistów przyjmującymi zdecydowanie rytualny charakter są: branding (piętnowanie), burning (wypalanie) i cutting (wycinanie) jako najprostsze w swoich formach skaryfikacje oraz typowe skaryfikacje przyjmujące postać tatuaży bliznowych (Myers 1992: 276-306). Dopełniając tej charakterystyki, warto zaznaczyć, że współczesnych prymitywistów nie interesują biologiczne i fizjologiczne aspekty ciała, gdyż to traktowane jest przez nich przede wszystkim jako wytwór społeczeństwa i jego kultury.

F. Musafar jest autorem listy siedmiu praktyk modyfikowania ciała, które jako sposób zabawy z ciałem mają prowadzić do uzyskania odmiennych stanów świadomości. Zalicza do nich: 1) modelowanie ciała (gimnastyka, joga, rozciaganie); 2) krępowanie ciała (bandażowanie, gorsetowanie, ściskanie); 3) deprywację sensoryczną (głodówka, brak snu); 4) obciążanie ciała (ciężkie bransolety, łańcuchy); 5) działanie ogniem (przypalanie, gorące prysznice); 6) penetrację ciała (biczowanie, przekłuwanie, tatuowanie); 7) podwieszanie ciała (wiszenie na hakach wbitych w skórę) (Vale, Juno 1989: 15). Musafar, który swoją przygodę z modyfikacjami rozpoczął jako trzynastolatek, przyznaje, że na własnej skórze doświadczył większości z wymienionych wyżej cielesnych modyfikacji. Opisując doświadczane w nich stany, mówi o odkrywaniu nowej rzeczywistości i wznoszeniu się na wyższe poziomy świadomej egzystencji (zob. szerzej Ambrosia, Lanza 1990: 106-117). Ten dziś osiemdziesięciosiedmioletni Amerykanin pozostaje stale aktywny w upowszechnianiu praktyk modyfikowania ciała poprzez wygłaszanie wykładów oraz organizację cieszących się dużą popularnością warsztatów, szkoleń i kursów. W ich trakcie prezentuje i uczy szamańskich technik, zwłaszcza w zakresie takich modyfikacji ciała jak piercing i branding.

Celem niniejszego tekstu, który przyjmuje postać socjologicznego studium badawczego nad ciałem podwieszanym, uczyniłam analizę doświadczania cielesności przez osoby praktykujące podwieszanie ciała (body suspension) jako jedną z form współczesnej body play. Według wiedzy i znajomości przez autorkę literatury przedmiotu, zagadnienie to nie zostało dotychczas w Polsce zbadane narzędzia$\mathrm{mi}$ socjologicznymi1. Podjęte badania wpisują się w rozwój socjologii ciała, zwłaszcza w tym jej nurcie, który nazywany jest socjologią ucieleśnienia (sociology of embodiment).

\section{Pierwotne formy podwieszania ciała}

Podwieszanie ciała w swojej pierwotnej formie nazywane było „Tańcem Słońca”. Praktykowali go rdzenni Indianie Ameryki Północnej, według wierzeń i światopoglądu których poprzez ciało można

${ }^{1}$ Wśród publikacji z zakresu socjologii ciała nie istnieja prace na temat praktyki podwieszania ciała, ktore mogłyby
zostać nazwane studiami badawczymi tego zjawiska. O podwieszaniu jako jednej z metod modyfikacji ciała udaje się wyczytać w większości podręczników z zakresu tej subdyscypliny socjologicznej. Są to jednak treści ujęte wyłącznie $\mathrm{w}$ systemy klasyfikacji sposobow przekształcania ciała. Ogólnie o modyfikacjach ciał współczesnych prymitywistów traktuje tekst zatytułowany ",Ciało jako obiekt operacji arty stycznej", ktorego autorem jest Jakub Cięzki (2006). Na równie zuje zjawisko podwieszania Dorota Majka-Rostek, traktujac te praktykę jak jedną z ekstremalnych modyfikacji ciała (2010). $\mathrm{O}$ wiele częściej temat body suspension podejmowany jest $\mathrm{w}$ ba daniach przez psychologów, antropologów i archeologów. kontaktować się ze światem duchów i demonów. Celem tej najstarszej i najsłynniejszej z indiańskich ceremonii miało być osiągnięcie stanu psychicznego pozwalającego nawiązać kontakt ze światem bytów pozazmysłowych. Warunkiem uzyskania upragnionej przed Indian wizji było samoudręczające poddanie ciała okrutnym torturom. „Wierzono, iż w czasie wizji Duch wchodzi w bezpośredni kontakt z człowiekiem, może sprawować nad nim opiekę lub udzielać mu skutecznych rad" (Gąssowski 1996: 162). W niektórych pracach źródłowych czytamy, że celem „Tańca Słońca” było „ślubowanie złożone przez mężczyznę". Nie wyklucza się też, że "Taniec Słońca” pierwotnie uważany był także za „rytuał płodności”(Cyrus 1997: 53).

"Taniec Słońca” pojawia się w antropologicznym opisie największego plemienia Zachodnich Indian, czyli Siuksów, autorstwa Elden Johnson: „Siuksowie, konni nomadzi, żyli przede wszystkim z polowań na bizony, mieszkali w tipi krytych bizonimi skórami, z ich skór wyrabiali rozmaite przedmioty trwałe i codziennego użytku. Znakomici w prowadzeniu wojen, zorganizowali się w zmilitaryzowanej społeczności opartej na więzach krwi, a za główny swój obrządek plemienny uznawali Taniec Słońca" (za: Teplicki 1994: 293). Tahca Ushte, czarownik Siuksów, uważa, że ofiara złożona w „Tańcu Słońca” jest oddaniem się Wakan Tanka (Cyrus 1997: 53). „Wakan Tanka uosabiał bóstwa dobroczynne, z których najważniejsze było Wi - Słońce" (Teplicki 1994: 300). Wierząc w nadprzyrodzone siły niebios, wód i ziemi, Siuksowie chcieli uzyskać z nimi kontakt. A ten możliwy był podczas snu, wizji lub majaczeń, w trakcie których dusza miała opuszczać ciało człowieka i obcować z nieziemskimi istotami. Jaki pisze dalej Zbigniew Teplicki (1994: 300), „,Siuks był zdolny do wszelkich poświeceń - głodował, przebywał w odosobnieniu, dopuszczał się samookaleczen i utraty krwi, gotów był tańczyć do upadłego - byle tylko w letargu lub w transie dowiedzieć się, jaki los zgotowali mu bogowie".

Uczestnikami tej ceremonii oprócz mężczyzn - tancerzy były także kobiety, które odgrywały znacząca rolę $\mathrm{w}$ jej przygotowaniach. Polegała ona na stawianiu pala (Cyrus 1997: 53). Ów „słup rytualny”, jak bywa nazywany w pracach źródłowych, odgrywał niezwykle ważną rolę w „Tańcu Słońca”. W opisie rytualnego wspinania się na drzewa u Indian autorstwa Mircea Eliadego (1997: 109) czytamy: „Drzewo lub słup uważane są za pośredników między ludźmi i bóstwem (Istota najwyższa lub Bóg solarny, Bohater kulturowy, Przodek mityczny itp.) albo za przedstawicieli, a niekiedy inkarnacje bóstwa. Innymi słowy, skuteczna komunikacja z bóstwem realizuje się przede wszystkim, jeśli nie wyłącznie, za pośrednictwem świętego drzewa lub słupa". Różny był scenariusz mityczno-rytualny "Tańca Słońca”. Jeden z jego najstarszych elementów polegał na wspinaczce na święte drzewo lub słup (Métraux 1943: 114, 117), która w swoim pierwszym znaczeniu u Indian Ameryki Północnej była określana jako „symboliczne wniebowstąpienie” (Eliade 1997: 111). W innym scenariuszu tancerze krążyli wokół świętego słupa, do którego byli przywiązani linami lub rzemieniami umocowanymi $\mathrm{w}$ ich ciałach za pomocą drewnianych kołków, a tańcząc, pozostawali cały czas zwróceni twarzą ku jego czubkowi (Cyrus 1997: 53). „Taniec Słońca” polegał też na podciągnięciu do góry na linach przymocowanych do centralnego pala w ten sam sposób przebitego ciała tancerza 
(Gąssowski 1996: 163). Poszczególne plemiona różniły się nie tylko przebiegiem, ale i częstotliwością tej ceremonii. U niektórych uroczystość ta odbywała się bardzo rzadko, inne plemiona organizowały ją co roku w czasie letniego przesilenia (Posern-Zielińska, Posern-Zieliński 1977: 101; Cyrus 1997: 53).

Rytuały polegające na torturach i okaleczaniu tancerzy były kultywowane przez większość plemion Indian Prerii, a szczególnie rozbudowane ich formy występowały $\mathrm{w}$ grupach sjuańskich. Według bardzo szczegółowego zapisu obserwacji przebiegu „Tańca Słońca” u Mandanów autorstwa XIX-wiecznego podróżnika i malarza George'a Catlina (1796-1872)², zanim przystąpiono do jego głównej ceremonii, uczestnicy wykonywali taniec błagalny. Polegał on na nieustannym wpatrywaniu się w słońce, a kiedy to zaszło - w święte przedmioty wiszące na centralnym słupie. Tancerze byli jak zahipnotyzowani, a sam taniec błagalny trwał kilka dni i nocy. Dopiero po nim następowała kulminacyjna część ceremonii „Tańca Słońca”, która w swej istocie polegała na obrzędowym torturowaniu kil$\mathrm{ku}$ dobrowolnie do niej przystępujących wojowników. Następujące po sobie akty tej uroczystości zaplanowane zostały w najmniejszych szczegółach. U Mandanów rytuał ten prowadził stary szaman pełniący funkcję mistrza ceremonii, który najpierw wypalał fajkę $w$ intencji tancerzy mających być za chwile poddanymi ofiarnym torturom. Miało im to pomóc stoczyć zwycięską walkę z bólem i własnymi słabościami. Jako że tancerze mieli już za sobą

${ }^{2}$ Na zapisie tej obserwacji poczynionej przez Catlina w 1834 wi rytuału "Tañca Słońca" u Mandanów, do której odwołuja sie w swojej publikacji Mirosława Posern-Zielińska i Aleksander Posern-Zieliński (1977). kilkudniowy post, w którym wstrzymywali się od jedzenia, picia i snu, niektórzy z nich, oczekując na rozpoczęcie głównego aktu „Tańca Słońca”, doświadczali mistycznych uniesień, w trakcie których sami siebie zaczynali torturować. Kolejny etap ceremonii polegał na przebijaniu ciała wojownika nożem używanym do skalpowania w sposób, który pozwoli w powstałym otworze umieścić drewniany kołek. Aby było to możliwe, czyli aby otwór w skórze był wystarczająco duży, a jednocześnie aby zadać tancerzowi większy ból, mężczyzna wykonujący tę czynność obracał nóż kilka razy w ranie. Do kołków umieszczonych na plecach i piersiach zawiązywano zwisające spod dachu namiotu grube rzemienie, by następnie na znak dany przez szamana podciągnąc je do góry wraz z zaczepionym na nich ciałem tancerza. Aby wzmóc doznania bólowe tancerza, do każdego z wystających z jego ciała kołków przywiązywane były przedmioty (łuki, strzały, tarcze, czaszki bizona), które dodatkowo napinały skórę. Tak obciążone ciało podciągano do góry na taką wysokość, aby wszystkie doczepione przedmioty uniesione zostały również nad ziemię. $\mathrm{W}$ następnym akcie ceremonii do każdego z młodzieńców podchodził mężczyzna, którego zadaniem było obracanie wiszącego w górze ciała po to, aby pomnożyć cierpienia uczestnika ceremonii i dowiedzieć się, jak długo jest on $\mathrm{w}$ stanie znosić zadawany mu $\mathrm{w}$ ten sposób ból. Do owego obracania zawieszonego pod sklepieniem namiotu ciała, najpierw delikatnego, a z czasem coraz szybszego i gwałtowniejszego, wykorzystywano długie kije. Zaprzestawano tej czynności dopiero wówczas, kiedy tancerze zaczynal krzyczeć z bólu, by następnie zamienić ten krzyk w błagalną modlitwę do Ducha-Słońce, w trakcie której oddawali się mu pod opiekę. W końcu, kie- dy błagania młodzieńców ucichły, co było równoznaczne z utratą przez nich przytomności, wszyscy „rytualni oprawcy” oddalali się. W końcowej części tego aktu ciała tancerzy wisiały bezwiednie i nieruchomo w górze, nie dając żadnego znaku życia. Na znak dany przez mistrza ceremonii ciała tancerzy zostawały opuszczone na ziemię. Nikomu z widzów tej uroczystości nie wolno było zbliżać się do omdlałych ciał wojowników, gdyż wierzono, że pozostają one pod opieką sił nadprzyrodzonych i tylko one mogą ich z tego stanu wyprowadzić. W końcu jeden z obserwatorów podchodził do nich po to, aby wyjąć kołki z piersi i pleców oraz uwolnić ciała od rzemieni. Przy czym warto tu zaznaczyć, że reszta kołków umieszczonych na ramionach, przedramionach, udach i łydkach wraz z zawieszonymi na nich przedmiotami nadal pozostawała $\mathrm{w}$ ciele tancerza. Po odzyskaniu przez wojowników przytomności, rozpoczynał się kolejny akt ceremonii, polegający na wędrówce ku czaszce bizona. Młodzieniec pełzał ostatkiem sił wzdłuż ścian pomieszczenia mocno krwawiąc, gdyż ciągle tkwiły $\mathrm{w}$ jego ciele rozszarpujące je ciężary. Kiedy udało mu się już pokonać tę drogę i dotrzeć do czaszki świętego zwierzęcia, tam składał siłom nadprzyrodzonym swoją kolejną ofiarę. Był nią mały palec lewej ręki. Torturowany opierał go na czaszce bizona, a siedzący przy niej „,funkcjonariusz kultu” amputował mu go toporkiem$^{3}$. Niektórzy tancerze słońca doznawali w tym akcie tak szczególnego uniesienia na skutek odczuwanych cierpień, że kazali sobie odrąbać również palec wskazujący u tej samej ręki albo mały palec ręki prawej. Za ten okaleczający ciało akt poświęcenia ofiarnik mógł liczyć na najwyższe uznanie spo${ }^{3}$ Tortury tej mieli dopuszczać się Indianie z plemienia Crow (Gąssowski 1996: 163). łeczne i wzrost prestiżu. Ostatni etap „Tańca Słonca" poprzedzony był krótkim odpoczynkiem jego uczestników, po którym tancerze zostawali wyprowadzeni z namiotu na centralny plac obozu. Do każdego $\mathrm{z}$ nich podchodziło po dwóch atletycznie zbudowanych mężczyzn, którzy mieli za zadnie owinąc nadgarstki tancerza mocno zaciśniętymi szerokimi rzemieniami. Tak przygotowani młodzieńcy mogli przystapić do „ostatniego wyścigu”, jak nazywany był końcowy akt tej ceremonii, który musiał odbyć się na oczach całej wspólnoty. Przy użyciu owych rzemieni mocno już storturowani młodzieńcy byl wleczeni przez młodych osiłków, którzy również przygotowywali się do udziału w tej ceremonii poprzez oddanie się przed nią długiemu wypoczynkowi. Najpierw ich krok był spokojny i miarowy, by następnie $\mathrm{w}$ nim przyspieszyć, aż wreszcie przejść do intensywnego biegu. $W$ stopniowaniu tempa tego "ostatniego wyścigu” chodziło o to, aby wojownik nie stracił od razu przytomności i jak najdłużej świadomie znosił ból. Celem tego wyścigu, który stanowił już kolejną $\mathrm{w}$ trakcie ceremonii „Tańca Słońca" próbę wytrzymałościową dla jego uczestników, miało być natomiast uwolnienie ciała tancerza od wszystkich umieszczonych w nim przedmiotów. Odbywało się to na przykład poprzez rozerwanie skóry o przeszkody terenowe występujące na drodze wyścigu. Ci widzowie rytuału, którzy chcieli skrócić męczarnie tancerzy, rzucali się na przedmioty doczepione do ich ciał, gwałtownie je $\mathrm{z}$ nich wyrywając. „Ostatni wyścig” odbywał się według ściśle określonych zasad, które dokładnie precyzowały sposób, w jaki wojownik może uwalniać się od ciążących mu przedmiotów. Jakiekolwiek z nich wyłamanie oznaczałoby obrazę świata duchów. Jeśli natomiast wszystko odbyło się w podporządkowaniu 
obowiązującym zasadom, ogłaszano „zwycięstwo tancerza nad martwymi przedmiotami”, czego dowodem były blizny na jego ciele, którymi wojownik z dumą chwalił się do końca życia. Ci tancerze, którzy w trakcie opisanej wyżej ceremonii wykazali się największą odpornością na cierpienia, uchodzili za ludzi obdarzonych nadprzyrodzoną mocą. Jako najbardziej wytrzymali i bohaterscy zostawali mianowani przez obserwujących ich udział w „Tańcu Słońca" wodzów i szamanów na dowódców wojennych akcji (Posern-Zielińska, Posern-Zieliński 1977: 102-105)

W związku z szerzeniem się misji chrześcijańskich i licznych restrykcji amerykańskiej administracji nastąił rozkład tradycyjnych wierzeń Indian. Znamienną w tym aspekcie datą jest rok 1881, kiedy to zabroniono wykonywania „Tańca Słońca”, jak i wszelkich rytuałów z nim związanych (Posern-Zielińska, Posern-Zieliński 1977: 110). Zamknięci $\mathrm{w}$ niewielkich rezerwatach Indianie porzucili swój dotychczasowy styl życia. Zniknięcie z Prerii zwierzyny łownej i wybicie bizonów spowodowało, że załamała się całkowicie gospodarka Indian oparta przecież na myślistwie. Stopniowo zaczęły upadać myśliwskie kulty. Indianie zaprzestali nawiązywania bezpośrednich kontaktów z siłami nadprzyrodzonymi, które niegdyś bardzo cenili. To dzięki tym kontaktom doświadczali mocy. Mogli też liczyć na protekcję w zdobywaniu żywności. Z czasem jednak Indianie jakby przestali potrzebować owej nadprzyrodzonej mocy. Pierwsze urodzone $\mathrm{w}$ rezerwatach dzieci poddane zostały edukacji narzuconej przez białego człowieka, która $\mathrm{w}$ dodatku odbywała się $\mathrm{z}$ dala od rodziny. Chłopcy przestali poszukiwać osobistego ducha opiekunczego, którego moc - jak dotąd wierzono miała im się przydać $\mathrm{w}$ myślistwie i prowadzeniu wojen. „To drastyczne przerwanie międzypokoleniowej transmisji dziedzictwa kulturowego spowodowało upadek całego systemu organizującego dotychczasowe życie religijne" (Posern-Zielińska, Posern-Zieliński 1977: 110). Szamanom, którzy nie mieli komu przekazywać plemiennych tradycji, całą swoją wiedzę i sztukę przyszło zabrać do grobu. I choć w 1933 roku zakaz odprawiania ceremonii „Tańca Słońca” przestał obowiązywać, to jednak nigdy już nie powrócono do jej pierwotnego scenariusza. I tak Siuksowie tańczą dziś wokół słupa, na zakończeniu którego widnieje pomalowana na czerwono czaszka bizona symbolizująca Słońce. Rytuał ten nie zawiera jednak dawnych form tortur jego uczestników (Teplicki 1994: 300).

\section{Teoretyczne ramy analiz empirycznych}

Prezentowane w niniejszym szkicu badania wpisują się w nurt badań socjologii ciała doświadczającego swojego ucieleśnienia (the sociology of the body understands embodiment), jak nazywa ją Arthur W. Frank (1991: 42). Za teoretyczną ramę badań prowadzonych nad zagadnieniem podwieszania ciała obrałam teorię fenomenologiczną $\mathrm{w}$ jej ujęciu filozoficznym autorstwa Maurice'a Merleau-Ponty'ego (2001), o której Chris Shilling (2010: 245) pisze, że „miała największy wpływ na kształtowanie apelu o powstanie "cielesnej socjologii»", (zob. szerzej Crossley 1995: 43-66). Richard Shusterman (2016: 77) uznaje go nawet za „świętego patrona ciała”, ponieważ nikt „nie był w stanie dorównać ogromowi wnikliwej, systematycznej i wytrwałej argumentacji, której Merleau-Ponty dostarczył, aby dowieśc prymatu ciała $\mathrm{w}$ sferze ludzkiego doświadczenia i znaczenia". Z tej perspektywy przejęłam zainteresowanie fizycznymi aspektami podwieszanego ciała, które skłoniło mnie do dociekań istoty doświadczania cielesności u osób poddających się tej praktyce. Skupiłam się zatem na tym, co Merleau-Ponty nazywa "cielesną tkanką" (zob. szerzej Merleau-Ponty 1996: 137-158), zdając sobie sprawę z tego, że znaczna część doświadczeń cielesnych badanych będzie się zasadzać na przeżywaniu ciała jako bytu materialnego składającego się z krwi, mięśni, kości i zmysłów. Ale ponieważ ciało w somatycznej fenomenologii Merleau-Ponty'ego (2001:425-426) jest „świadomością milczącą” i „nieartykułowanym ujęciem świata" , chcąc dociekać ekspresyjnej roli podwieszanego ciała, nie mogłam czerpać inspiracji wyłącznie od tego autora. Merleau-Ponty niewiele wszak uwagi poświęca odczuciom ciała. R. Shusterman (2016: 8), pisząc o cichym i chromym ciele w filozofii, dostrzega, że Merleau-Ponty „prawie w ogóle nie chce słuchać tego, co ciało o sobie «mówi» za pomocą swych samoświadomych doznań, takich jak wyraźne kinestetyczne lub proprioceptywne odczucia". Choć oczywiście taka postawa autora jest przez niego samego dostrzegana i ma służyć określonym celom jego koncepcji filozoficznych, opis ekspresywności ciała za pomocą milczenia nie mógł stanowić wystarczająco szerokiej ramy teoretycznej dla moich badań. Poza doświadczaniem ciała jako „mięsa” $(\text { flesh })^{4}$ interesowało mnie żywe doświadczanie ucieleśnienia badanych praktykujących podwieszanie ciała. Dlatego ramy swoich analiz poszerzyłam o koncepcję Leib Edmunda Husserla (1982), uznawanego za twórcę tak zwanej nowej fenomenologii. Od tego ostatniego autora przyjęłam wyjściową dla moich badań definicję ciała ludzkiego, o którym Husserl (1982: 141) pisze w taki oto sposób: „,moje własne ciało (...) jako jedyne wyróżnia się tym, że nie jest samą tylko cielesną bryła, lecz właśnie ciałem żywym (Leib), jedynym obiektem w obrębie mojej poprzez abstrakcje uzyskanej warstwie świata, któremu opierając się na doświadczeniu przypisuję posiadanie pól wrażeniowych (Empfindungsfelder), pól przynależnych do niego, choć na różne sposoby (pole wrażeń dotykowych, pole wrażeń ciepła i zimna itd.)". Przeciwstawiając Leib ciału fizycznemu (Körper), podkreślał wyposażenie tego pierwszego w tak ważny atrybut jak wola. Husserl podkreślał duchowo-cielesny charakter egzystencji. Twierdził, że człowiek nie tylko ma ciało, ale też odczuwa, że jest swoim ciałem, nazywając je „nosicielem zlokalizowanych wrażeń" (Husserl 1974: 203-208). Uwzględniając kontekst doświadczania własnej cielesności w trakcie praktyki podwieszania, ciało każdego z badanych interesowało mnie zatem również jako ciało żyjące, odczuwające i emocjonalne.

Przyjęcie za strategię gromadzenia i analizowania danych metody teorii ugruntowanej oznacza, że najistotniejsza staje się perspektywa badanych jako aktorów zaangażowanych w omawiany rodzaj praktyki cielesnej. Dlatego też przedstawione powyżej ujęcia teoretyczne nie spełniają tu roli samopotwierdzających się teorii. Faktem jest natomiast to, że perspektywa fenomenologiczna, w obu zaprezentowanych koncepcjach, stanowi istotny punkt wyjścia do autorskich prób teoretyzowania ciała w których najważniejsze pozostaje mocne ugruntowanie $w$ danych empirycznych. 


\section{Problematyka i metoda badań}

Problematyka prezentowanych badań dotyczyła percepcyjnego doświadczania ciała, jego obecności i zaangażowania $\mathrm{w}$ praktykę podwieszania. Wobec przyjęcia w nich perspektywy podmiotu starałam się przede wszystkim wsłuchać $\mathrm{w}$ to, co na temat swoich ciał mają do powiedzenia badani. Zbieranie i analizowanie materiału empirycznego zostało podporządkowane procedurom metodologii teorii ugruntowanej (Konecki 2000; Charmaz 2009; Glaser, Strauss 2009). Zgodnie z jej założeniami w realizacji badania posłużyłam się techniką wywiadu swobodnego ukierunkowanego, w przeprowadzeniu którego korzystałam z przygotowanych wcześniej dość ogólnie sformułowanych dyspozycji. Posługując się celowym doborem próby, badaniami objęto osoby praktykujące podwieszanie ciała ( $\mathrm{N}=30)$, które uczestniczyły w podwieszaniu zarówno w trakcie kameralnych spotkań bez udziału publiczności, jak i podczas otwartych konwentów. Za kryterium włączenia do badań przyjęto co najmniej dwukrotne doświadczenie bycia podwieszanym na hakach za skórę 5 . Wywiad trwał od 120 do 150

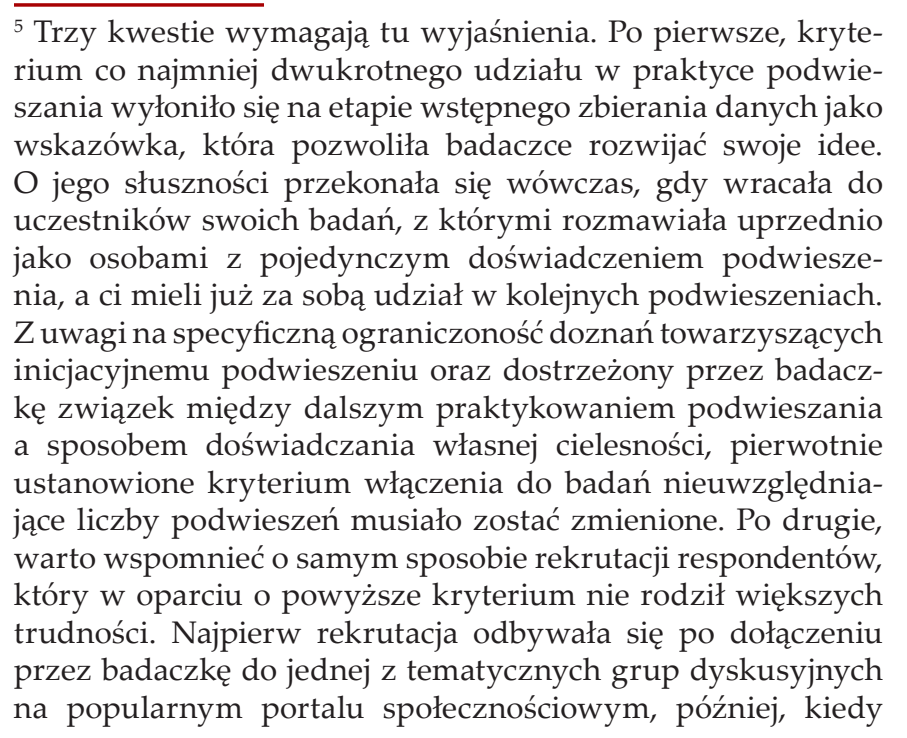
Trzy kwestie wymagają tu wyjaśnienia. Po pierwsze, krytezzania wyłoniło się na etapie wstępnego zbierania danych jako zmawiała uprzednio . zwizzek miedzy dalzy ora dostozezony prodwieszania a sposobem doświadczania własnej cielesności, pierwotnie jące liczby podwieszeń musiało zostać zmienione. Po drugie, przez badaczke do jednej $z$ lja odbywała się po dołączeniu na popularnym portalu społecznościowym, później, kiedy minut, a uzyskane $\mathrm{w}$ jego trakcie informacje były rejestrowane, a następnie poddane transkrypcji. Analiza fenomenologii wcielenia badanych w kontekście praktyk podwieszania ciała, $\mathrm{w}$ podporządkowaniu zasadom metody teorii ugruntowane w danych, odbywała się według następujących etapów: 1) konceptualizacja materiału jakościowego obejmująca rzeczowe kodowanie danych (najpierw otwarte, następnie selektywne); 2) utworzenie kategorii będących zespołami kodów, które uzyskałam poprzez łamanie danych; 3) konceptualizacja własności kategorii; 4) odkrywanie powiązań występujących pomiędzy kategoriami. Jedną z takich kategorii okazało się „,doświadczanie ciała” obejmujące doznania i wrażenia cielesne badanych, które stały się centralną kategorią poniższych analiz empirycznych. Zgodnie z paradygmatem metodologii teorii ugruntowanej czynności zbierania i analizowania danych nie odbywały się $\mathrm{w}$ rozdzieleniu czasowym od siebie, a przeciwnie, stale się ze soba przeplatały. Generowanie teorii (generation of theory) będące istotą metodologii teorii ugruntowanej jest procesem długotrwałym ${ }^{6}$, który ,,jest kontrolowany przez wyłaniającą się teorię, czy to rzeczową czy

nastapiła już konfrontacja $z$ empiryczną rzeczywistością, re-

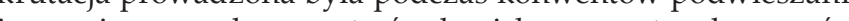
i organizowanych przez to środowisko prywatnych seansów. przedstawia bogata dokno do wy wadu, każdy z badanyc jego udział w kolejnych praktykach podwieszania. Po trzecie wreszcie, doprecyzowanie techniczne w nazwie praktyki ma znaczenie z punktu widzenia istnienia kilku odmian podwieszania, miedzy innymi np. pullingu, który również polega na wbiciu hakow w skorę, choc sam przebieg praktyki jest juz zgoła inny. Uczestnicy pullingu tańczacc w okregegu, naciagaja liny dołaczone do umieszczonych $w$ ich ciele haków po to, aby ling od standardowego podwieszania jest brak elementu unoszenia ciała do góry.

teorie wygenenerować. Traktuje go raczej jako szkic etnograficz ny, który stanowi wstępną ramę analityczną do procesu teoretyzowania. formalną" (Glaser, Strauss 2009: 41). Aby zapobiec pojawieniu się w tej teorii tego, co jako badacz jakościowy nazywam „ciemnymi przestrzeniami”, proces teoretycznego pobierania próbek (theoretical sampling) oparłam na kluczowej dla niego metodzie „permanentnej analizy porównawczej” (constant comparative method). Kiedy w dostarczanych danych nie pojawiały się już nowe własności wypreparowanych kategorii, nabrałam empirycznej pewności o ich "teoretycznym nasyceniu" (theoretical saturation) (Konecki 2000: 31-32).

\section{Charakterystyka badanej grupy}

W badanej grupie osób praktykujących podwieszanie ciała znalazło się 16 mężczyzn i 14 kobiet. Badani są ludźmi młodymi, mieszczącymi się w przedziale wiekowym 21-29 lat. Studiują bądź już ukończyli studia wyższe na takich kierunkach jak promocja zdrowia, weterynaria, zootechnika, multimedia ze sztuką, antropologia czy historia. Co się tyczy sfery aktywności zawodowej respondentów, to zakres ich działalności zarobkowej jest bardzo zróżnicowany. W objętej badaniem grupie znaleźli się reprezentanci takich profesji jak aktor, pracownik naukowo-dydaktyczny na uczelni wyższej, nauczyciel, przedsiębiorca, kamieniarz, szewc czy sprzedawca. Wśród badanych były też osoby, które $\mathrm{w}$ chwili przeprowadzania $\mathrm{z}$ nimi wywiadu zajmowały się piercingiem, instruktażem narciarstwa i wspinaczki, projektowaniem graficznym, dekoratorstwem wizualnym oraz działalnością ekologiczną. Niektórzy z badanych w tym czasie stawiali swoje pierwsze kroki w branży modelingu. Dominującą cechą stanu cywilnego badanych było pozostawanie $\mathrm{w}$ hetero- bądź homoseksu- alnych związkach partnerskich. Wszyscy badani zamieszkiwali miasta liczące powyżej 100 tysięcy mieszkańców. Znamienną i również dominująca cechą była deklarowana areligijność badanych.

Nakreślony wyżej socjodemograficzny portret badanych dopełnią te dane, które w sposób bezpośredni bądź pośredni wiążą się z działaniem skierowanym na własne ciało. Badani praktykujący podwieszanie jako osoby świadomie i aktywnie zainteresowane pracą nad swoim ciałem, zwłaszcza w kontekście jego wizerunku, są właścicielami ciał w znacznym stopniu zmodyfikowanych. $W$ badanej grupie znalazły się osoby posiadające takie modyfikacje ciała jak tatuaż, piercing, przypalania i cięcia przyjmujące postać skaryfikacji, implanty transdermalne i subdermalne oraz deformacje kości czaszki. Wśród badanych były również osoby posiadające w swoich ciele wszczepione implanty magnetyczne. Respondenci oddają się również systematycznej aktywności fizycznej, odwołując się do takich jej form jak: pływanie, jazda rowerem, wspinaczka, snowboard, narciarstwo alpejskie, boks tajski, treningi siłowe, joga, morsowanie. Wspólną cechą badanych jest poddawanie się określonym reżimom dietetycznym, w szczególności diecie wegetariańskiej i wegańskiej. Badanych określa też deklarowana wrażliwość wobec zwierząt, która znajduje potwierdzenie $\mathrm{w}$ aktywności $\mathrm{w}$ organizacjach pozarządowych działających na rzecz ich humanitarnego traktowania. Osoby wchodzące w skład badanej grupy deklarują powiązania z kulturą body modification, kulturą psychodeliczną, kulturą BMX i szeroko rozumianą kulturą postindustrialną. Wśród gatunków słuchanej przez nich muzyki dominuje hardcore punk lub punk oraz gatunki muzyczne mieszczące się w szerokim 
pojęciu muzyki postindustrialnej, „okołoelektronicznej" czy eksperymentalnej, na przykład tekno. Mocno eksponowane przez badanych były ich powiązania z fandomem fantastycznym. Ci badani, którzy ujawniali swoje powiązania z subkulturami punkowymi, określali się jako zwolennicy ruchu straight edge, definiując się jako osoby o wysokim poziomie samoświadomości i skoncentrowane na coraz lepszym poznawaniu siebie, a przy tym nie pijące alkoholu, nie biorące narkotyków, nie jedzące mięsa, niezainteresowane przypadkowym seksem, a swoje ciało traktujące jak świątynię.

Istotne dla poniższych analiz są te dane charakteryzujące badanych, które wprost odnoszą się do praktykowania przez nich podwieszania ciała. Jedną z nich jest informacja dotycząca wieku badanych w momencie inicjacyjnego podwieszenia. I tak, najniższy wiek respondenta $\mathrm{w}$ chwili pierwszego podwieszenia to 17 lat, najwyższy to 27 lat. Badani są zaangażowani $\mathrm{w}$ działalność kilku istniejących na terenie Polski grup popularyzujących podwieszanie jako formę zabawy z ciałem7. Miejscem ich spotkań są imprezy gromadzące ludzi o niestandardowych zainteresowaniach, takie jak na przykład Festiwal Castle Party czy też konwenty tatuażu czy piercingu stanowiące okazję do spotkania osób o podobnym stosunku do własnej cielesności. Ważnym wydarzeniem są organizowane przynajmniej raz $\mathrm{w}$ roku w jednym $\mathrm{z}$ dużych miast w Polsce (Wrocław, Warszawa, Łódź, Kraków, Gdańsk, Katowice) konwencje body suspension, nazywane w żargonie badanych

${ }^{7}$ Charakterystykę polskiej sceny podwieszania ciała zawarłam w innej mojej publikacii, która została w całości poświęcona motywom praktykowania współcześnie podwieszania ciała (Kowal 2016: 75-76). „susconami”. W rzeczywistości wirtualnej badani pozostają skupieni wokół magazynu internetowego „BME - Body Modification Enzine” oraz licznych grup zarówno otwartych, jak i zamkniętych łączących osoby zainteresowane praktyką podwieszania ciała na popularnych portalach społecznościowych (np. Facebooku). Jedną z najważniejszych przestrzeni komunikacji ze środowiskiem osób zainteresowanych szeroko rozumianymi modyfikacjami ciała jest forum bodymodifications.net ${ }^{8}$, na którym wielu badanych publikuje fotografie posiadanych modyfikacji cielesnych. Wiedzę o podwieszaniu, jego typach i pozycjach czerpią przede wszystkim z Body Modification Enzine Encyclopedia ${ }^{9}$ która zawiera indeksowany opis wszystkich możliwych modyfikacji cielesnych wraz z treściami graficznymi. Wśród badanych są osoby partycypujące w pracach utworzonego w roku 2016 The International Suspension Allian$c e^{10}$, który jako organizacja non-profit ma za zadanie jednoczenie społeczności osób praktykujących podwieszanie, realizację działań o charakterze badawczym, edukacyjnym i pomocowym oraz popularyzowanie w różnych kręgach odbiorców informacj o bezpiecznym przeprowadzaniu podwieszania.

\section{Analiza materiału empirycznego}

Podwieszanie ciała na hakach za skórę zawsze odbywa się według określonego porządku. Jako że

${ }^{8}$ Forum skupia obecnie 6248 członków pochodzacych z róż nych krajow swiata. Członkowie polskiej narodowosci są trze znajduje się pod adresem: https://bodymodifications.net/ [dostęp 18.03.2017 r.].

9 Body Modification Enzine Encyclopedia znajduje się pod adresem: https://wiki.bme.com/index.php?title=Main_Page [dostęp 17.03.2017 r.].

Strona internetowa ISA znajduje się pod adresem: http://suspension.org [dostęp 10.03.2017 r.]. interesowały mnie wszystkie szczegóły tej praktyki, postaram się, aby opis doświadczeń podwieszanych możliwie dokładnie oddawał wrażenia i przeżycia badanych na każdym z następujących po sobie etapów podwieszania. Oprócz aspektów związanych z doświadczaniem przez podwieszanych określonych doznań interesowała mnie także strona techniczna i organizacyjna tej praktyki.

\section{Wbicie haków w ciało}

Przekłucie hakami skóry, poprzedzone krótkim rozluźniającym masażem, jest pierwszym etapem podwieszania ciała, a zarazem momentem rozpoczynającym doświadczanie ciała jako źródła bólu. Doświadczanie wrażeń bólowych, które w sposób nieodłączny każdorazowo towarzyszy wbijaniu haków w ciało, według relacji badanych nie jest ani sensem, ani celem praktykowania podwieszania. W badanej grupie nie było takich osób, które czerpałyby przyjemność z doznawania odczuć bólowych jako takich. Co więcej, największą obawą, która pojawiała się u badanych przed przystąpieniem do inicjacyjnego podwieszenia, była właśnie ta związana z nieuniknionością bólu:

Strasznie się bałem. Wiedziałem, że będzie boleć, ale nie wiedziałem, jak to będzie boleć. Przed pierwszym podwieszeniem stał obok mnie chłopak, który miał być podwieszany przede mną. Bawił się nerwowo swoimi kolczykami i powiedział, że jest bardzo spanikowany. Pode mną wtedy się nogi głęboko ugięły. Wielu ludziom podwieszanie ciała kojarzy się z jakąś formą masochizmu czy autodestrukcji. Ja jestem natomiast bardzo spokojnym człowiekiem i nigdy w życiu nie zadałem sobie bólu, nawet nie umiałbym sobie przekłuć ucha. Nie umiem sobie sam zadać bólu. Ja się go zawsze boję. Nie mam żadnych zapędów autodestrukcyjnych, szanuję swoje ciało. (M, 23 lata)

Już chciałem mieć ten moment przebicia za sobą Ja się najbardziej bałem samego wbijania haków. Rozmiar tych igieł i haków mnie przerażał. Bardzo się denerwowałem. Postanowiłem zacisnąc zęby przy przekłuwaniu skóry i jakoś to przeżyć. (M, 23 lata)

Pozycję podwieszenia, spośród wielu propozycji możliwych figur, wybiera sama osoba podwieszana. Od wyboru konkretnej pozycji zależeć będzie liczba haków, którymi przekłute zostaną powłoki skórne osoby podwieszanej. W pojedynczym akcie podwieszenia wykorzystuje się od kilku do kilkunastu haków, które po umieszczeniu w tkance skórnej łączy się za pomocą lin wspinaczkowych ${ }^{11}$. $\mathrm{W}$ podyktowaniu sformułowanymi powyżej obawami przed doświadczeniem silnego bólu badani wybierają, zwłaszcza przy pierwszej próbie podwieszania ciała, pozycje najprostsze, wśród których największą popularnością cieszy się pozycja suicide. Przypominająca figurę powieszonego samobójcy, stosunkowo łatwa w realizacji, wymaga wbicia $\mathrm{w}$ ciało osoby podwieszanej niewielkiej

${ }^{11}$ Haki używane do podwieszania są jednorazowe bądź sterylizuje się je nasyconą parą wodną pod ciśnieniem w autoklawie $\mathrm{w}$ standardowym cyklu piętnastominutowym $\mathrm{w}$ temperaturze 121 stopni Celsjusza. Osoby zaangażowane w przekluwanie tkanki skornej mają założone na dłonie podwójne rekkawiczki, najpierw jednorazowe, a następnie sterylne. Od ilosici użytych materiałów, haków, środków opatrunkowych waha sie $w$ granicach 350-500 złotych. Niniejsze informacje uzyskałam $\mathrm{w}$ trakcie wywiadów pogłębionych $\mathrm{z}$ pierceram odpowiedzialnymi za wykonywanie przekłuć u podwieszanych osób. 
liczy haków, z reguły dwóch, maksymalnie czterech, jeśli wymaga tego jej waga ${ }^{12}$.

Badani przypisują duże znaczenie kwestii samodzielności nie tylko $\mathrm{w}$ obszarze podejmowania decyzji o samym podwieszeniu, ale też o wszystkich dalszych sprawach z nim związanych, w tym przede wszystkim pozycji podwieszania i jej własnego przeprojektowywania. Wynika to nie tylko z poczucia jednostkowej wolności przystępujących do tej praktyki, ale także silnie eksponowanego przekonania o ciele jako obiekcie własności, nad którym badani przejmują władzę i kontrolę. W podwieszaniu ciała, podobnie jak i w posiadanych już jego modyfikacjach, urzeczywistnia się wola badanych, którzy wszelkie działania skierowane na ciało traktują jako swoją prywatną sprawę i element obranego stylu życia. Nie sposób też nie dostrzec w poniższych wypowiedziach tego, że badani pozostają w silnym tożsamościowym związku z własnym ciałem:

Mojego ciała nikt mi nie jest w stanie odebrać, więc jest ono moje. Pozycję zawsze wybieram sam. Bardzo nie lubię, jak ktoś inny mi się do tego wtrąca. Ja muszę zawsze sam sobie wszystko zaplanować. Rozrysowuję sobie najpierw pozycję, którą chcę zrobić, gdzie haki, gdzie bloczki, wszystko zależy ode mnie. Jeśli robie jakieś ryzykowne rzeczy, to zawsze z przygotowaniem, zawsze to jest przemyślane. Zawsze staram się być odpowiedzialny za swoje ciało. (M, 23 lata)

${ }^{2} Z$ informacji uzyskanych $\mathrm{w}$ trakcie wywiadów $\mathrm{z}$ osobami lechnicznie zaangażowanymi $\mathrm{w}$ podwieszanie wynika, że czać 60 kilogramów. Zachowanie takiego przeliczenia ma zapobiec sytuacjom naderwania skóry czy ugięcia się haka podpobiec sytuacjom naderwania skory czy ugiectia
czas unoszenia osoby podwieszanej do góry.
Ciało to jest taki mój dom. Jest moje i niczyje inne nie będzie. To jest zupełnie naturalne i oczywiste. To jest miejsce, w którym muszę żyć przez całe życie, więc muszę o nie dbać. Ale mogę z nim robić, co chcę Oczywiście w pewnych, ale wyznaczonych przeze mnie granicach. Nie pozwoliłabym mojemu ciału zrobić krzywdy. (K, 23 lata)

Jako osoby, dla których ciało pozostaje obiektem świadomego i całkowitego posiadania, badani starają się też optymalnie przygotować fizycznie do podwieszenia. Służyć ma temu zjedzenie lekkiego posiłku, relaksująca kąiel oraz wykonanie tuż przed podwieszeniem ćwiczeń rozciągających poszczególne używane $\mathrm{w}$ wybranej pozycji partie mięśni. O poczuciu osobistej odpowiedzialności za własne ciało świadczyć też może to, że badani nie spożywają przed podwieszeniem alkoholu.

Za realizację obranej pozycji podwieszenia odpowiada członek ekipy technicznej, który kształtuje tę figurę poprzez precyzyjne rozmieszczenie na ciele osoby podwieszanej wbijanych w skórę haków. Z tym zabiegiem wiąże się jeszcze jeden typ obaw przystępujących do podwieszenia. Jako osoby, które na co dzień pozostają mocno skoncentrowane na wizerunku własnego ciała, obawiają się tego, że umieszczenie w tkance skórnej określonej liczby haków zaburzy kształt i estetykę posiadanych już czy planowanych modyfikacji cielesnych. Uwzględniając przyszłe konsekwencje podwieszania, o których stanowią popodwieszeniowe blizny oraz ślady po ewentualnym naderwaniu powłok skórnych, w sposób szczególny troszczą się o to, by haki zostały rozmieszczone tak, aby wkomponowały się we wzór posiadanych dekoracji skóry, czyli tatuaży i skaryfikacji.
U mnie trzeba było się trochę bardziej z hakami „nagimnastykować" w kontekście tatuażu. Tak, żeby te blizny były tak jakoś wkomponowane, żeby nie było ich widać. Martwi mnie też kwestia blizn ze względu na to, że planuję kiedyś wytatuować te miejsca, za które się podwieszam, a tatuaż na bliźnie zachowuje się jednak inaczej.(K, 23 lata)

O ile ból jest tym, co przerażało badanych, zwłaszcza $\mathrm{w}$ oczekiwaniu na inicjacyjne podwieszenie, to $\mathrm{w}$ treści ich obaw nie sposób jednak doszukać się tych, które miałyby coś wspólnego z ryzykiem związanym z naruszeniem ciągłości powłok skórnych oraz ingerencją $\mathrm{w}$ organizm, która nie ma przecież charakteru terapeutycznego. Ten aspekt zagrożeń wobec ciała właściwie nie pojawia się w wypowiedziach osób podwieszanych, a wywołany przez badaczkę zostaje uznany za niemający uzasadnienia w sytuacji, jeśli przekłuciami zajmują się specjaliści na co dzień wykonujący różne formy modyfikowania ciała, $\mathrm{w}$ tym przede wszystkim piercerzy i tatuatorzy. Ich wiedza z zakresu anatomii i fizjologii ciała ludzkiego przekłada się na zaufanie, jakim obdarzają je osoby poddawane podwieszaniu. W swojej formie zarządzania ciałem jako prywatnym zasobem tę część kontroli nad ciałem badani zdają się przekazywać właśnie tym osobom:

Wiedziałam, kto to jest i wiedziałam, że ci ludzie zajmują się tym długo i są w tym dobrzy. Wiedziałam, że jeżeli rzeczywiście przerwie się skóra i trzeba będzie szyć, to wiedziałam, że ci ludzie sobie z tym poradzą. Wiedziałam, że to nie będzie karetka i jechanie do szpitala, tylko to oni mnie uspokoją i zszyją. (K, 23 lata)
Obserwowałam wcześniej ich pracę, ich zaangażowanie i profesjonalizm. Oni zdają sobie sprawę z powagi sytuacji, że można komuś zrobić krzywdę. Ale wszystko było na tip-top. Wszystkie nieszczęścia, które mogły wyniknać z niedopatrzenia, zostały wyeliminowane. Żadne niedopatrzenie nie było możliwe. (K, 27 lat)

Dopóki relacje ciała z obiektami fizycznymi i innymi ludźmi są bezproblemowe, ciało znika ze świadomości. Drew Leder (1990: 1), wywodzący swoją koncepcję tożsamości z fenomenologii percepcji M. Merleau-Ponty'ego, ów stan „cielesnej nieobecności” nazywa „zapominalstwem”. Pojawienie się bólu w trakcie przekłuwania powłok skórnych sprawiało natomiast, że badani stawali się bardzo mocno świadomi swojego fizycznego ciała. Ból jawi się tutaj jako syndrom „dys-zjawienia się ciała” (Leder 1990: 84). Choć ciało podwieszane nie jest ciałem chorym, uobecnia się w sposób znany ze stanu dysfunkcji cielesnej. Odczucia bólowe świadczą o pewnym oporze, jaki stawia materialne ciało, które według badanych zdawało się już na początku podwieszania przejmować nad nimi władzę:

Przy wbijaniu haków jest ogromny ból. I ten ból narasta. Bardzo, bardzo boli. To jest naprawdę bardzo nieprzyjemne. Nic więcej się nie czuje. Tylko boli. (M, 23 lata)

Było to bardzo nieprzyjemne uczucie, takiego tępego bólu. Taki tępy ból właściwie na sporym obszarze ciała. Nie tylko w miejscach przekłuć. No po prostu popłakałam się z bólu. (K, 28 lat)

Bardzo bolesny jest moment wbijania haków. Nawet na zdjęciach jestem wykrzywiony z bólu. (M, 29 lat) 
Jeśliby chcieć sprecyzować stosunek badanych do bólu, którego doświadczali na pierwszym etapie praktyki podwieszania, to oczywiście należałoby uznać, że jego świadome przeżywanie nie było potrzebą badanych. Czy zatem można uznać ból wyłącznie za uboczny skutek podwieszenia, nie przypisując mu żadnego większego znaczenia? Czy jeśli byłaby możliwość jego uniknięcia, chcieliby go doświadczać? Na pełne rozstrzygnięcie tych kwestii pozwolą dopiero analizy doświadczania przez badanych własnego ciała na kolejnych etapach praktyki podwieszania.

\section{Uniesienie ciała do góry}

$\mathrm{Z}$ emocjonalnego punktu widzenia najtrudniejszym etapem podwieszania jest według relacji badanych ten, który poprzedza bezpośrednio moment oderwania się od ziemi. To $\mathrm{w}$ pewnym sensie stan przejściowy, wszak linki i skóra są już naprężone, osoba mająca być podwieszaną stoi na palcach, ale ciągle jeszcze nie odrywa się od podłoża. Doświadcza już bólu, choć zdaje sobie sprawę z tego, że po oderwaniu stopami od podłoża odczucia bólowe będą jeszcze silniejsze. Kiedy uznaje swoją gotowość przejścia do kolejnego etapu, daje podwieszającym sygnał, po którym zaczyna być unoszona do góry. Według relacji badanych, ten moment zawsze oznacza eskalację najintensywniejszych doznań bólowych wywołanych gwałtownym naprężaniem skóry przy niemalże równoczesnym odrywaniu tkanki skórnej od warstwy mięśniowej:

Pojawia się ból, takie napięcie skóry tuż przy hakach. Czuć coraz większe to napięcie, tak jakby skóra się wydłużała w tych miejscach. Czuć taką plastykę skóry. Im wyżej znajduję się w górze, tym boli to bardziej. (K, 23 lata)

Na tym etapie praktyki podwieszania ciało doświadczane jest nade wszystko jako byt materialny. To jeden z momentów w podwieszaniu, w którym badani wchodzą $\mathrm{w}$ relację z ciałem określaną przez Bryana S. Turnera jako posiadanie ciała (having a body). Ciało pozostaje tutaj czymś zewnętrznym wobec jednostki, wiedzie odrębny, autonomiczny żywot (Turner 1992: 16-17, 40-41). W trakcie unoszenia do góry badani stawali się mocno świadomi fizyczności swojego ciała, które w sposób niekontrolowany zdawało się wykraczać poza granice własnej somatyczności. Działo się tak za sprawą pojawienia się krwi, która zaczynała płynąć z miejsc aplikacji haków:

Jak już miałem wbite haki, to wstałem z tej kozetki, na której leżałem podczas wbijania haków i poszedłem parę kroków do miejsca, w którym miałem być podwieszony. Podciągnięto mnie do góry, a ja popatrzyłem na dót, że pode mną jest czerwono. Praktycznie była pode mną kałuża krwi. (M, 23 lata)

I to właśnie z powodu niedających się uniknąc a wywołanych tą praktyką cielesną objawów fizyczności ciała badani doświadczali na tym etapie oporu w konfrontowaniu się wzrokowym z własnym ciałem:

Myślałem długo nad pozycja „kwiatu lotosu”, w nie się siedzi w takiej pozycji (tu respondent demonstruje - przyp. autorki). Zrobiłem ją, tylko że tak naprawdę ja nie byłem gotowy na taką pozycję, żeby włączyc jeszcze wzrok i widzieć to wszystko. Bo jak ta skó- ra jest taka naciaggana, trochę zawsze widać tkankę tłuszczowa. I to już jest za dużo dla mnie. Nie jest mi to potrzebne, żeby to widzieć. (M, 23 lata)

Wśród odbieranych tutaj doznań zmysłowych na uwagę zasługują te, które odbierane są przez zmysł słuchu. Jeśli bowiem osoba podwieszana zdecyduje się na praktykowanie podwieszania w zupełnej ciszy, w chwili unoszenia ciała do góry słyszy subtelny i bardzo specyficzny odgłos zasysanego pod powłoki skórne powietrza.

Jeszcze wyraźniejszy niż na poprzednim etapie opór, jaki stawia materialne ciało, sprawia, że badani znów zaczynają doświadczać własnego ciała jako tego, które przejmuje nad nimi władzę. To jeden $\mathrm{z}$ tych momentów, w których pojawia się myśl o zakończeniu praktyki podwieszania. Tym, co w sposób najbardziej znaczący ogranicza badanych, jest ból fizyczny, który obnaża przed nimi słabość ciała. Doświadczając tego bólu, osoba podwieszana czuje się w tym momencie sprowadzona do swojego ciała. Czuje się wyłącznie fizycznym ciałem:

Przy samym podciąganiu czułem tylko, że skóra mi się rozciąga na kolanach. Zamknąłem oczy, aby nie patrzeć, ale i tak czułem tylko to, że ta skóra się tak naciąga. Było takie uczucie, którego nie mogę porównać z niczym innym. Czułem się tak, jakby mnie tam nie było, a było samo ciało, właściwie tylko skóra, która się naciagga i boli. (M, 23 lata)

ak już byłam podwieszana, to czułam haki w plecach, bardzo mocno wtedy skupiałam się na ciele. Czułam jak mnie ciągnie skóra, że to mnie boli. (K,
To właśnie na etapie unoszenia ciała do góry najczęściej dochodzi do naderwania tkanki skórnej czy zupełnego jej przerwania pod ciężarem ciała, a także niekontrolowanego krwotoku bądź omdlenia. Te wszystkie stany, silnie zakorzenione w fizyczności ciała, rodzą konieczność przedwczesnego zakończenia praktyki podwieszania, co w rezultacie oznacza uznanie prymatu ciała. Ci, którzy tego doświadczyli, mówili w tym kontekście o nieporadzeniu sobie $\mathrm{z}$ własnym ciałem:

Moje ciało było rozdrażnione tym wszystkim, bo najpierw było wbijanie dwunastu haków, to jest sześć serii po dwie osoby. To było dla niego zbyt ciężkie. Jeden z piercerów trafił mi hakiem w naczynko i podczas unoszenia do góry straciłem sporo krwi. Musieliśmy wstrzymać podwieszanie. (M, 23 lata)

Suspension było dla mnie naprawdę niemiłym przeżyciem. Byłam podwieszana za plecy $i$ to była zła decyzja w moim przypadku. Bo ja jednak mam silnie umięśnione plecy od uprawiania sportu i wydaje mi się, że trzeba było wybrać inne miejsce. Wyczekiwałam tego momentu, kiedy poczuję to jakieś mistyczne uczucie, o którym wszyscy mówili. Jak mnie unosili do góry, to zrobiło mi się z bólu bardzo niedobrze i musiałam być bardzo szybko opuszczona na dół Było mi bardzo słabo. Zemdlałam po prostu. (K, 21 lat).

Aby zapobiec przedwczesnemu zakończeniu praktyki podwieszania, wysiłek badanych zostaje nakierowany na rekonceptualizacyjną pracę z bólem, czyli osiągnięcie takiego poziomu kontroli w relacji ciało-umysł, który umożliwi im zapanowanie nad stwarzanymi przez ich własne ciało ograniczeniam 
fizycznymi. Niezwykle pomocne okazują się tutaj metody pracy z oddechem, który badani próbowali świadomie spowolnić, by osłabić doznania bólowe.

Podwieszanie ciała nie jest praktyką wymagającą od osoby podwieszanej opanowania określonej techniki czy posiadania specjalnych zdolności. Nie ma też obostrzeń, które bezwzględnie wykluczałyby z niej osoby niespełniające określonych kryteriów dotyczących na przykład wagi bądź wzrostu ${ }^{13}$. Nie każdy jednak może przystąpić do podwieszenia ciała. Nie powinna $\mathrm{w}$ tej praktyce uczestniczyć między innymi osoba posiadająca niski próg wrażliwości bólowej, niedostateczne krzepnięcie krwi czy cierpiąca na skazę krwotoczną bądź anemię. Istotnym warunkiem praktykowania podwieszania ciała jest posiadanie ciała zdrowego.

\section{Lot jako ucieczka do wewnątrz ciała}

Lot rozpoczyna się w momencie, kiedy osoba podwieszana znajdzie sięjuż na optymalnej dla wybranej pozycji wysokości zawieszenia. Według relacji badanych opisujących przeżycia towarzyszące im $\mathrm{w}$ tym momencie trwania praktyki, jest to najistotniejszy etap podwieszania. Od chwili całkowitego zawiśnięcia na hakach, które nazywane jest przez badanych „,byciem na hakach”, zaczynają doświadczać poczucia oddzielenia się od ciała. Niektórzy nazywali ten stan "opuszczeniem własnego ciała” czy „uwolnieniem się od ciała”, co wiązało się

${ }^{3}$ Za warunek udziału w podwieszaniu ciała uznaje się wiek. Staraniem organizatorów konwencji podwieszania oraz ekip
odpowiedzialnych za ich strone techniczna jest, aby cheć udziału w podwieszaniu zgłaszały osoby petnoletnie. Jako badaczka zagadnienia stwierdzam, że kryterium to nie zawsze est przestrzegane. Etyczna strona tego procederu nie będzie jednak przeze mnie rozważana w niniejszym tekście. głównie z zaprzestaniem odczuwania bólu bądź jego znacznym osłabieniem, które następuje po tym, jak ból w trakcie unoszenia ciała do góry osiąga poziom najwyższy. Dalsze jego doświadczanie $\mathrm{w}$ takim natężeniu nie byłoby zdaniem badanych możliwe:

Jak już byłam podciągana do góry, ten ból był tak wielki, że ja czułam, że dalej nie dam rady. Ale kiedy byłam już w górze, poczułam, że nagle przestaję go czuć, a napływają we mnie naprawdę silne pozytywne emocje. (K, 27 lat)

Opisane powyżej doświadczenia posiadają wyraźnie symboliczny charakter. Lot jako „bycie w powietrzu" jest dla badanych synonimiczny z poczuciem wolności. Unoszenie do góry ma oznaczać ucieczkę od ciała, za sprawą którego osoba podwieszana doświadcza bólu. Ból, który jawi się tutaj jako symbol wszelkich słabości, zostaje zastąpiony przez przyjemne doznania. Unoszenie się nad ziemią daje osobom podwieszanym nade wszystko świadomośc pokonania ciała i wyzwolenia ze stwarzanych przez nie ograniczeń. Uniesienie ciała do góry ma oznaczać wreszcie tryumf umysłu nad fizyczną cielesnością i początek doświadczania doznań o charakterze ponadcielesnym:

To było takie wyjście z ciała, mógłbym siebie obserwować z boku. Obserwowałem, jak moje ciało wiruje, ciężko jest mi to opisać. To jest tak, jakbym wyszedł ze swojego ciała, bo już go kompletnie nie czułem. Jakbym uciekł ze swojego ciała. (M, 23 lata)

Czułam, że to jest piękne. Bardzo silne emocje i rzeczywiście taka fascynacja. Potem wzruszenie. Mia- łam ochotę rozpłakać się ze szczęścia i w końcu to zrobiłam. Ja się kompletnie nie bałam. Ja byłam szczęśliwa! Czułam się jak mała dziewczynka. Huśtałam się i byłam coraz bardziej radosna. (K, 27 lat)

To była po prostu ogromna euforia. Do dziś zdarza mi się oglądać zdjęcia z podwieszania, to ja mam na nich po prostu taki uśmiech na twarzy, jaki mi się chyba nigdy nie zdarzył. Było to uczucie, którego nigdy w życiu nie doświadczyłam. (K, 28 lat)

Analizując przeżycia towarzyszące osobom podwieszanym w tej fazie praktyki, którą oni sami nazwali "lotem", nasuwa się pytanie o istotę owego poczucia oddzielenia się od ciała czy jego opuszczenia doświadczanego w podwieszaniu. Czy poza wymiarem symbolicznym można tu rzeczywiście mówić o ucieczce od ciała, które emituje nieprzyjemne doznania bólowe? W odpowiedzi na tak sformułowane pytanie od razu nasuwa się konstatacja dotycząca nieodzowności doświadczania ciała w jego wymiarze materialnym, które staje się narzędziem do osiągnięcia wszystkich przyjemnych stanów następujących później. Dosłowna ucieczka od ciała nie jest tu zatem możliwa, wszak ciało staje się narzędziem pozwalającym przeżywać pożądany przez osoby podwieszane stan odmienionej świadomości. Nawet jeśli badani doświadczają tu poczucia uwolnienia się od wszelkich ograniczeń i słabości ciała, z których najistotniejszym w tej sytuacji jest ból, to nie jest to jeszcze równoznaczne $z$ osiagnięciem stanu bezcielesności. Doświadczali oni wszak czegoś znacznie głębszego. To rodzaj ucieczki do wewnątrz ciała, jakże różnej od pozornie doświadczanej ucieczki od ciała oraz od codziennej ucieczki badanych w ciało, której sensem jest przede wszystkim koncentracja na jego zewnętrznej powłoce. Badan zdawali się być tutaj pogrążonymi we własnej cielesności. Docierali do „wnętrza” ciała, które stawało się im dostępne $\mathrm{w}$ akcie podwieszania. Badający zjawisko masochizmu w relacji do jaźni amerykański psycholog Roy T. Baumeister w podobny sposób przedstawia sens bólu w praktykach seksualnych o tym charakterze. Sensem masochizmu i doświadczanego w nim bólu ma być ucieczka do swojego „ja” cielesnego, czyli takie świadomościowe zbliżenie się do ciała, które pozwala uznać, że w tym konkretnym momencie jest się swoim ciałem i tylko ciałem. Stan ten oznacza tymczasowe wyłączenie wszystkich komponentów społecznej tożsamości i doświadczanie siebie tylko i wyłącznie na drodze zmysłowej (Baumeister 1988:28-59; zob. szerzej Baumeister 1989). Owa ucieczka do wewnątrz ciała pozwalała osobom podwieszanym doświadczyć tego, co nazywali „pozytywną samorealizacją, „zdarzeniem jednoznacznie pozytywnym”, „zachwytem”, „,berserkowskim uniesieniem”, ,„euforią”, „głębokim ukojeniem”, „stanem błogości” czy wreszcie „duchowo-cielesną ekstazą", ,"doznaniem szczy towym" i „momentem największego szczęścia i spełnienia”. Mimo różnych określeń używanych do oddania tego stanu, jego wspólną definicją jest uznanie go za szczytowy moment wejścia w związek ciałem i najintensywniejsze jego doświadczenie. Istotą tego doświadczenia jest afirmacja „wnętrza”, aż po zupełne w nie wycofanie. „A skoro cielesność jest kluczowym elementem tożsamości, owa ucieczka do wewnątrz ciała stwarza szansę na odnalezienie swojego prawdziwego «ja», co badani wiążą właśnie z dostąpieniem wyższego poziomu świadomości" (Kowal 2016: 89). Oto przykładowe relacje badanych opisujące te przeżycia: 
Trzeba być naprawdę pewnym, że tego się chce, bo to naprawdę może odmienić na zawsze. To jest taki bliski kontakt ze swoim ,ja", to jest takie niesamowite uczucie... Podwieszanie jest dla mnie sposobem bycia ze sobą tak blisko i w tak bardzo ekscytujący sposób. Ja po prostu teraz wiem, kim jestem. (K, 27 lat)

Po prostu czułam inny stan świadomości. Było mi w nim cały czas tak świeżutko, czułam się tak niesłychanie rześko. Jakbym się urodziła właśnie. Poczułam kontakt z własnym „ja”, bo żyjemy na co dzień w takim świecie, w którym człowiek nie koncentruje się tak na sobie, nie zna całej swojej istoty bycia. A mi podwieszanie pozwoliło na taki bliski kontakt ze soba. (K, 27 lat)

Ten bliski związek z ciałem, które nie stawia w tym momencie podwieszania oporu, a staje się częścią ,ja" osoby podwieszanej oznacza ten typ relacji, który B. S. Turner nazywa "byciem ciałem” (being a body) (Turner 1992: 16-17). W rezultacie takich doświadczeń autorzy powyższych wypowiedzi traktowali podwieszanie jako szczytową i ostateczną praktykę cielesną, która ma być świadectwem ich dojrzałości i zwieńczeniem poszukiwań własnej tożsamości.

Niektórzy z badanych przypisywali swoim doświadczeniom charakter mistyczny. Zwłaszcza że w owej ucieczce do wewnątrz ciała tracili kontakt z otoczeniem, przy jednoczesnym odczuwaniu z nim jedności, a ponadto zaburzeniu ulegała ich percepcja czasu. A takie doznania są właściwe doświadczeniom szczytowym (zob. szerzej Maslow 1986: 74-118). Osobom podwieszanym trudno na ogół określić, jak długo trwało ich podwieszenie w tym szczytowym momencie praktyki. Czas trwania praktyki podwieszania liczony od momentu uniesienia osoby podwieszanej do góry do momentu dotknięcia przez nią ponownie stopami podłoża w przypadku badanych wynosił od 5 do 60 minut. Doświadczanie zmienionego poczucia czasu ma swoje konsekwencje dla indywidualnego przebiegu podwieszania. $W$ percepcji cytowanego niżej badanego czas w trakcie podwieszenia płynie wolniej, dlatego jest go więcej na podjęcie decyzji o wykonywaniu czynności nieodzownych dla właściwego przebiegu zaplanowanej pozycji:

W pięknych okolicznościach przyrody, bo nad Morzem Śródziemnym, robiłem podwieszanie z odcinaniem sobie lin. Najpierw odcinałem liny połączone z hakami na plecach. Był moment, w którym miałem już ten nóż w ręce, miałem już go przy linkach na plecach, no i podobno z perspektywy obserwatorów to było błyskawiczne, trzy sekundy i po wszystkim, ale z mojego punktu widzenia to był niesamowicie długi czas. Długo zastanawiałem się, czy to zrobić i czy na pewno. Wydawało mi się, że to było 5-10 minut, zanim zdecydowałem się odciąc te linki. (M, 28 lat)

Jeśliby dopełnić opisu owych niezwykłych stanów świadomości, których badani doznawali w trakcie podwieszenia, to według ich własnych odniesień bliski jest on stanowi narkotycznego odurzenia, jakkolwiek nie może być z nim w pełni utożsamiany, biorąc pod uwage wartość przeżyć. Na zestawienie tych przeżyć pozwala to, że badanym znane są doświadczenia zmienionego stanu świadomości wywoływanego za pomocą środków narkotycznych:
Podwieszanie daje coś znacznie bardziej silnego i intensywnego niż po zażyciu psychodelików czy uprawianiu intensywnie sportu. To bardzo mocne doświadczenie. (M, 28 lat)

Ten stan, w którym się jest, jest taki pseudonarkotyczny. Jest się na takim naturalnym haju, ludzki mózg całkiem inaczej pracuje w takich sytuacjach. (...) Do tej pory nie odnalazłem jeszcze nic, co by mi tak spasowało, jeśli chodzi o te przeżycia. (M, 23 lata)

Branie narkotyków czy czegoś innego to jest tylko ułuda, a w tym momencie jest się z samym sobą, z samym sobą i... to, co się wytwarza, te emocje... to jest prawdziwe. (K, 27 lat)

Według badanych nie istnieje nic, co byłoby im znane, do czego można by przyrównać doznania ekstatyczne przeżywane $\mathrm{w}$ trakcie podwieszania. Jeśli nawet $\mathrm{w}$ badanej grupie znalazły się osoby, które porównywały podwieszanie ciała do opium, to od razu zastrzegały, że jego oddziaływanie jakościowo znacznie przewyższa doznania opiumowe i trwa dłużej, bo znacznie wykracza poza czas trwania samego podwieszenia.

Na tym etapie podwieszania badani doświadczają też w znacznym zakresie poczucia utraty kontroli nad własnym ciałem, czego przejawem miały być, jak nazwał to jeden z badanych, „dziwne rzeczy dziejące się z ciałem". Mowa tutaj przede wszystkim o poczuciu nieważkości, w którym ciało traci swój ciężar, a także towarzyszącym mu drżeniu i wibracjach ciała oraz jego mimowolnym poruszaniu się. Ciało zawieszone na hakach jest w ciągłym ruchu. Niekiedy wydobywa się z niego krzyk, płacz bądź głośny śmiech jako uzewnętrznienie bezsprzecznie przyjemnych doznań o charakterze orgazmicznym:

Moje ciało zaczyna wirować, jak na karuzeli. Huśtam się. Tylko że na karuzeli często się robi niedobrze. A podczas podwieszania totalnie tego uczucia, że jest mi niedobrze od tego wirowania, nie było. Wcześniej tego uczucia nigdy nie czułem, że kręci mi się w głowie, ale dobrze się $z$ tym czuję. (M, 23 lata)

To było takie bardzo silne przeżycie, takie orgazmiczne mocno, można to porównać $\mathrm{z}$ takim dobrym orgazmem, takie też eksplorujące. Nigdy tego wcześniej nie czułam. Potem, jak już się przyzwyczaiłam do tego stanu, to straciłam kontrolę nad ciałem i emocje zaczęły nim zupełnie władać. Odpłynęłam, totalnie! (K, 27 lat)

Ja się totalnie wyłączyłem. Zacząłem brzydko mówić, żyć tylko w swojej głowie, zacząłem się nakręcać tą adrenaliną. Takie buzowanie czułem. Nie chcę użyć słowa „zwierzęce", ale budziły się we mnie takie najprostsze instynkty. (M, 28 lat)

W doświadczaniu opisywanych stanów badani zdają się też dystansować od swojego materialnego ciała. To, co dzieje się z nim w trakcie podwieszania badani reflektują jako śmieszne i wprawiające ich w zdumienie: „Moje ciało robi coś takiego"? Podobne odczucia towarzyszą im zresztą podczas oglądania fotografii i filmów dokumentujących to wydarzenie już po zakończonym seansie podwieszania. To właśnie te przeżycia uprawniały osoby podwieszane do odczuwania tego, że w tym konkretnym momencie nie są do końca swoim fizycznym ciałem. 
Ciało materialne zaczyna tu bowiem odrębny żywot, staje się bytem mniej tożsamym z osobą podwieszaną:

Najdziwniejszą rzeczą jest to, że nie stąpam nogami po ziemi, to takie dziwne uczucie. Nie mam nóg na ziemi. To jest taki stan fizycznej nieważkości. Nie bardzo mogę się w tym stanie przekręcić, nie bardzo mogę coś z ciałem zrobić. Samo się właściwie tylko buja i huśta. Cieleśnie czuję się jak lalka. Takie dziwne uczucie. (K, 23 lata)

Mimo tych ograniczonych możliwości sprawowania kontroli nad ciałem $\mathrm{w}$ fazie lotu, osoba podwieszana pozostaje świadoma jego obecności. Ciało materialne nie znika tu całkowicie, żaden $\mathrm{z}$ badanych nie definiował się $w$ tym momencie jako byt bezcielesny. Zachowana świadomość ciała wykorzystywana jest do podejmowania działań zmierzających do intensyfikacji wynikającej z sensorycznych doświadczeń przyjemności, co polega na przykład na wymachiwaniu rękami, odbijaniu się rękoma i nogami od podłogi i ścian czy wykonywaniu określonych układów tanecznych. Właściwie w każdej kolejnej praktyce podwieszania badani starają się zintensyfikować doznania przeżyte podczas wcześniejszych podwieszeń. Eksperymentowanie z ciałem polega również na aplikowaniu $\mathrm{w}$ nie coraz większej liczby haków bądź też modyfikowaniu samej pozycji podwieszania poprzez wzbogacanie jej nowymi miejscami przekłuć czy też dociążaniu podwieszonego ciała przedmiotami:

Na pewno będę starał się robić bardziej ekstremalne pozycje. Zawsze mówię sobie, że muszę dać z siebie wszystko. Muszę to coś jeszcze bardziej poczuć. Co podwiesza- nie mam coraz więcej haków w sobie, bo robię coraz trudniejsze pozycje. (M, 29 lat)

Ale to nie na działaniach pozostaje skupiona osoba podwieszana, co pozwala dostrzec $\mathrm{w}$ tej praktyce cielesnej Foucaultowską „technikę siebie”. Autor tej kategorii pojęciowej mówi tutaj o skupieniu umysłu na „emocjach, myślach, doświadczanych pragnieniach, zapale poszukiwania $\mathrm{w}$ sobie wszelkiego ukrytego uczucia. Każdego poruszenia duszy, każdego pragnienia przebranego w iluzoryczne formy" (Foucault 2000: 247). Narzędziem do tego wykorzystywanym musi być jednak ciało i zachowana $\mathrm{w}$ fazie lotu świadomość cielesna. Ta ostatnia sprawia, że osoba podwieszana koncentruje się na wrażeniach sensoryczno-zmysłowych, co ma polegać na odgrodzeniu się od tych, które pochodzą z otoczenia zewnętrznego, przy równoczesnym otwarciu się na te docierające $\mathrm{z}$ „wnętrza" ciała. Według relacji badanych $\mathrm{w}$ trakcie podwieszenia wszystkie przedmioty i ludzie znajdujący się w zasięgu ich wzroku wydają się być w dekoncentrującym, a wręcz drażniącym ich ruchu. Dlatego osoby podwieszane przystępując do swoich kolejnych podwieszeń, zakładają opaskę na oczy, co ma służyć właśnie izolacji od wszelkich bodźców zewnętrznych w trakcie trwania fazy lotu:

Najmniej istotną rzeczą jest to, co jest dookoła. O tym się nie myśli. Tego się nie czuje. Trzeba wyłączyć pewne receptory, pewne zmysły, które postrzegają wszystko, co jest wokół. Skupić się na jednych, a wyłączyć drugie. Nie przeszkadzałoby mi na przykład, jakby zgasło wszędzie światło. Nie potrzebuję wtedy zmysłu wzroku. I tak oczy zamykam. Skupiam się zupełnie na sobie. (M, 23 lata)
Nie wszystkie bodźce zewnętrzne są jednak tymi, które zakłócają przeżycia osoby podwieszanej. Jej przyjemne doznania sensoryczne są intensyfikowane przez zmysł słuchu. Niektórzy badani, zanim jeszcze przystąipili do podwieszenia, jako tło tej praktyki wybierali ulubiony przez siebie utwór muzyczny. Muzyka pozostaje wszak ważną częścią praktyki podwieszania ciała. Ponieważ jej dźwięki są najczęściej znane osobie podwieszanej, ten rodzaj bodźców nie tylko wzmaga przyjemne doznania płynące z samego podwieszania, ale też osłabia lęk przed bólem:

Miałam zamknięte oczy i słuchałam muzyki. Muzyka mi bardzo pomogła. Ta muzyka sprawiała, że ja pozwoliłam sobie być tam, gdzie mnie prowadziła wyobraźnia. (K, 27 lat)

Leciała moja ulubiona muzyka. A ja bawiłam się pod sufitem, bardzo dynamicznie. Dzięki tym dźwiękom, które do mnie docierały, było bardzo dużo zabawy, to moje doświadczenie było takie bardzo mocno radosne. (K, 28 lat)

Ci badani, którzy szansy na spotęgowanie przyjemnych stanów w trakcie podwieszania upatrywali w eksplorowaniu jego bardziej rytualnych form, sięgali po pozycję klasyczną, inspirowaną ceremoniami Okipa, w której haki umieszczone zostają w skórze na klatce piersiowej (Bowers 2004: 111-156). Według badanych, którzy zostali podwieszeni w tej pozycji, jest ona trudniejsza i bardziej bolesna niż popularna pozycja suicide. Silniejsze doświadczenie bólowe ma być zatem warunkiem osiągnięcia $w$ jego następstwie stanów przyjemnościowych o wyższym natężeniu. Zdarza się, że uzyskany przyjemny stan nie satysfakcjonuje osoby podwieszanej. Zgodnie z instrukcją badanych w takiej sytuacji należy zintensyfikować doznania bólowe poprzez samodzielne wykonywanie na przykład gwałtownych szarpnięć ${ }^{14}$. We wspomnianej pozycji suicide źródłem dodatkowych doznań bólowych, które badani świadomie wywoływali w fazie lotu, było niełatwe w realizacji unoszenie rąk w sposób opisywany przez jednego z badanych:

Należy unieść ręce w bok, tak aby zachować kąt dziewięćdziesięciu stopni między korpusem. To potrafi być zaskakująco bolesne i nieprzyjemne. (M, 28 lat)

Treścią jednego z ważnych ustaleń analitycznych jest wyraźna zależność między sprawnością podwieszanego ciała a czerpaniem przyjemności z tej praktyki. Większa sprawność ciała przekłada się na wybór "gimnastycznych" pozycji podwieszania, do których badani zaliczali choćby pozycje „skorpiona”, siedząca pozycję „,kwiatu lotosu” czy podwieszenie w szpagacie. Nawet jednak przy wyborze najprostszych pozycji podwieszania większa sprawność cielesna sprzyja wykonywaniu w górze różnych układów tanecznych, którymi osoba podwieszana wzbogaca wybraną pozycje podwieszenia, a tym samym pogłębia własne doznania. Wydaje się zatem, że owa sprawność ciała (fitness) nie powinna być tu utożsamiana wyłącznie $\mathrm{z}$ jego fizycznymi umiejętnościami. „W «sprawności» idzie nie tyle o to, do jakich wyczynów ciało jest zdolne, ile o to, jak głębokie są doznania przeżywane

"Za źródło takich instrukcji służą badanym opisy „Tańca Stońca" u Czejenów, według scenariusza którego podwieszeni tancerze mieli wisieć w górze długie godziny, co jakiś czas szarpiacc się na linach po to, aby wywołać silniejszy ból, a osta-
tecznie uzyskać upragnioną wizję (Gąssowski 1996: 163). 
w toku ich dokonywania. Idzie głównie o wrażenia - które winny być «pasjonujące», «zachwycające», «czarujące», ekstatyczne" (Bauman 1995: 91). W opisie przeżyć tych badanych, u których doszło do znużenia doznaniami uzyskiwanymi $\mathrm{w}$ klasycznych pozycjach podwieszania ciała, dostrzegalny jest mechanizm eskalacji kolejnych przyjemnych wrażeń, który prowadzi do sięgania po jego najbardziej ekstremalne formy. Zazwyczaj organizowane $w$ plenerze, $w$ języku środowiska podwieszanych i podwieszających określane są jako freefall $^{15}$. Potęgowanie i wydłużanie czasu trwania przyjemnych doświadczeń odbywa się w takim podwieszeniu nie tylko poprzez bodźce płynące z otoczenia przyrodniczego, ale też wyrafinowaną technikę samego podwieszenia ${ }^{16}$ oraz większy zakres aktywnej partycypacji osoby podwieszanej $\mathrm{w}$ jego przebiegu:

Kiedy odcinałem pierwsze liny, to było szarpnięcie związane z obciążeniem pozostałych haków, a potem była błogość i stan nieważkości. Potem, kiedy poodcinałem pozostałe liny, byłem zawieszony jakby w powietrzu przez ułamek sekundy i tu miałem znów taki moment nieważkości i błogostanu. Po tym było jakieś tam kręcenie czy fikołki. I po tym następuje takie szarpnięcie za pozostałe haki, na które dość gwał-

${ }^{15}$ Jednym z największych wyczynów typu freefall było podwieszenie Crissa Angela w pozycji suicide z helikoptera przelatujacego nad gorami w Dolinie Ognia w Nevadzie, ktore zostało zrealizowane na potrzeby programu telewizyjnego zatytułowanego Mindfreak jego własnego autorstwa. W organizacji tego projektu uczestniczył Allen Fa
czesnego podwieszania ciała.

16 Wśród planowanych przez badanych podweszé maja znaleźć sie te mocno osadzone w konwencii freefall, czyli na przykład skok z klifu, bedac zawieszonym na linach z umiejscowionymi w ciele hakami, latanie na paralotni, bedac podwieszonym na hakach czy podwieszenie ciała doczepionego do wyciągu narciarskiego. towanie zwiększa się nacisk. I tu znów mega przyjemność. Po tym jak wpadłem do wody, to czułem od słonej wody pieczenie ran, co dawało mi dalej przyjemność. (M, 28 lat)

To właśnie intensywność cielesnej ekspresji w połączeniu z wydłużonym czasem lotu są przedstawiane przez badanych jako warunek uzyskania stanu (naj)wyższej świadomości równoznacznego z doznaniem zmysłowej transcendencji. Według relacji badanych tylko wówczas można doprowadzić do swoistego wykroczenia poza doznania podstawowych pięciu zmysłów i zejścia ciała do stanu porównywalnego z omdleniem. Odwołując się do przypadku Michela Foucaulta, którego jedną z głównych idei było kultywowanie ciała i przyjemności, R. Shusterman wyraża pewien niepokój związany z postulowaną przez tego pierwszego koniecznością poddawania ciała gwałtownym doznaniom w celu zwiększenia somatycznej przyjemności i w ogóle pojawienia się świadomości ciała. „Stałe zapotrzebowanie na ekstremalnie silne doznania jak pisze Shusterman - grozi nie tylko zmniejszeniem zakresu odczuwanej przyjemności, ale nawet przytępieniem naszej afektywnej przenikliwości przytępieniem samej zdolności do odczuwania naszych ciał z prawdziwą jasnością, precyzją i mocą" (Shusterman 2016: 64)

W kontekście odbierania wrażeń zmysłowych przez osobę podwieszaną należy zaznaczyć również ważną do odegrania rolę osoby podwieszającej. Oprócz jej technicznego zaangażowania w praktykę ma ona też chronić podwieszanego przed zakłóceniem jej przebiegu przez innych uczestników czy obserwatorów. W trakcie trwania podwieszania staraniem członków ekipy technicznej jest, aby nikt nie podchodził do osoby podwieszanej, co mogłoby zostać zinterpretowane jako nie tylko chęć zakłócenia, ale wręcz zawłaszczenia jej przeżyć. Te ostatnie są wyłączną „własnością" osoby podwieszanej. Erving Goffman, traktujący ciało jako materialną własność jednostki, nazwałby przestrzeń osoby podwieszanej jej „terytorium Ja”, które należy rozumieć nie tylko jako miejsce podwieszenia, ale także tę „najmniejszą możliwą przestrzeń osobistą", jaką jest "swoisty rezerwat" ciała wyznaczony granicą cielesnej powłoki (Goffman 2011: 47-62). Osoba podwieszana zostaje zatem niejako odizolowana od reszty uczestników w intymności swoich doznań. Ma być sam na sam ze swoimi przeżyciami:

Ja byłam na takim kameralnym podwieszeniu, było tam zaledwie dwadzieścia osób. Ale ja poprosiłam, żeby reszta wyszła. Ja nie chciałam żadnego audytorium. Chciałam zostać sama. To jest moje własne ciało, moje haki, moja skóra i nie chcę nikogo więcej. Zostali oczywiście ci, którzy mnie podwieszali, jakieś trzy, cztery osoby, które musiały sprawdzać to wszystko i czuwać, by nikt mi nie przeszkadzał. Szkoda, że to nie jest rzecz, którą można by zrobić samemu w sypialni. (K, 23 lata)

Nie sposób też nie dostrzec tu po raz kolejny symboliki aktu podwieszania, w którym osoba podwieszana zostaje $\mathrm{w}$ dwójnasób wywyższona. Po pierwsze, odbywa się to poprzez fakt fizycznego podciągania na linach do góry, by tam przez jakiś czas pozostać zawieszoną. Po drugie, osoba podwieszana zostaje tutaj uprzywilejowana przez fakt swoich przeżyć. Wyraźnie odczuwalny staje się tutaj prymat jednostki nad grupą:
Czuję się wtedy taki jedyny, czuję się wtedy, jakbym był pępkiem świata. Jakbym był tylko ja. Cała uwaga skupiona jest na mnie. (M, 29 lat)

Tylko na wyraźne życzenie osoby podwieszanej dopuszcza się przy niej obecność kogokolwiek. Na ogół jest to ktoś z bliskich jej osób, którego rola (o ile pozwala na to dana pozycja) polegała na trzymaniu uczestnika podwieszenia za rękę od początku do końca trwania etapu lotu, czyli czasu, w którym pozostaje on zawieszony na hakach. To jeden z nielicznych społecznych akcentów tej praktyki cielesnej, w którym stymulacja przyjemności płynącej z podwieszenia ciała odbywa się przez dotyk czy w ogóle kontakt fizyczny $\mathrm{z}$ inną osobą. Ta bezpośrednia interakcja fizyczna osoby podwieszanej z wybraną osobą towarzysząca może przybrać bardzo intymny charakter. Jedna z jej form polega na dociążeniu osoby podwieszanej poprzez „doczepienie się" do jej ciała kogoś bliskiego. Dodatkowym źródłem rozkoszy staje się wspólne podwieszenie $\mathrm{z}$ bliską osobą. W trakcie "tańca w górze" uczestnicy, choć zawieszeni na odrębnych linach, w kulminacyjnym dla siebie momencie w sposób zaplanowany bądź nie przytulają się do siebie, by przez jakiś czas wisieć razem w uścisku. Zwłaszcza, że podwieszanie okazuje się nie tylko celebrowaniem transcendencji, ale także celebrowaniem nagości. Osoby podwieszane przystępują do tej praktyki cielesnej z reguły półnadzy, a zdarza się, że nadzy. Odsłonięcie ciała, nawet jeśli zostaje ono wystawione na widok szerszej publiczności, nie stanowi dla osoby podwieszanej problemu. Aspekt wstydu w ogóle nie pojawia się $\mathrm{w}$ tym kontekście $\mathrm{w}$ wypowiedziach badanych: 
Nie zastanawiałam się w tym momencie kompletnie nad tym, jak, jak wyglądam. Nie miałam wtedy takiego podręcznikowo pięknego ciała. A byłam rozebrana, musiałam się trochę obnażyć. Nie wstydziłam się. To mnie w tym momencie najmniej interesowało. Ja myślę sobie, że chciałabym kiedyś podwiesić się całkiem topless $\mathrm{w}$ pozycji suicide. (K, 27 lat)

Intensyfikacja doznań w trakcie podwieszenia dokonuje się także przez świadomość bycia w centrum zainteresowania innych. Skupienie uwagi na osobie podwieszanej, wyrażany wobec niej podziw daje nie tylko dodatkową motywację, ale też wzmaga jej przyjemne doznania:

Ja lubię, jak inni patrzą na mnie, jak się podwieszam. To jest przyjemne. To mi dodaje jeszcze większej adrenaliny. Ja wtedy wiem jeszcze bardziej, że muszę to zrobić. Gdybym to zrobił na scenie przed stu piećdziesięcioma osobami, to wydaje mi się, że mógłbym przejść przez kolejną granicę i poczuć ten błogostan. Ci ludzie, ich obecność daje mi to, że przez jakiś moment swojego nudnego życia czuję się kimś wyjątkowym. Czuję się jak król w tym momencie. Jestem tym nakręcony. Wszyscy biegają wokół mnie, kontrolują haki, patrza, robią zdjęcia. Czuję wtedy, że jestem królem tej imprezy. Czuję się doceniony, a jak człowiek jest doceniony, to jest szczęśliwy. (M, 29 lat)

W trakcie podwieszania jego uczestnicy komunikują się za pomocą swoich ciał z przyglądającą się tej praktyce publicznością. Treść tych komunikatów sprowadza się do manifestacji własnej indywidualności, odwagi oraz władzy nad ciałem. Ale jest to również okazja do wystawienia na widok publiczny swojego w znacznym stopniu zmodyfikowanego ciała, w czym uobecnia się ten typ relacji z ciałem który określany jest jako robienie ciała (doing a body) (Turner 1992: 16-17). Dlatego przyjemność doświadczana przez osoby podwieszane jako aktorów tego przedstawienia bierze się również ze świadomości, że wzbudzają zainteresowanie publiczności i są podziwiani już nie tylko za to, co robią $\mathrm{w}$ tym momencie ze swoim ciałem, ale też za to, jak ono wygląda. $\mathrm{Z}$ obrazu ciał badanych daje się natomiast wyczytać kontestację dominującego nurtu, w którym definiowane i kreowane jest dziś ludzkie ciało. Ci badani, którzy podwieszanie uznają za body art, wystawienie ciała podczas otwartych konwencji podwieszania traktują jako wyraz protestu wobec obowiązujących w ponowoczesnej kulturze wzorców przekształcania ciała. Tak zaznaczony sprzeciw badanych okazuje się jednak kontestacją wyłącznie estetycznych norm, którym ma być podporządkowane ciało. Ekspozycja ciała w trakcie tej praktyki pozostaje w dużej mierze poza kontrolą podwieszanych, którzy próbują w ten sposób przywrócić własnemu ciału fizyczność. Odsłonięte partie ciała mają być przedstawione tak, aby podkreślić ich zwyczajną, naturalną cielesność

Nie przejmuję się tym, że moje piersi po prostu zwisaja sobie, że nie mam wyrzeźbionego ciała, że brzuch $\mathrm{m}$ tam gdzieś odstaje, bo nie jest super płaski i wyćwiczony, że mam cellulit, bo uważam, że każda kobieta go ma i taka jest po prostu nasza uroda. (K, 27 lat)

W sposobie odnoszenia się do swojego ciała w trak cie podwieszania badanym nie udaje się jednak do końca zerwać z narcyzmem kultury konsumpcyjnej, w której, jak głosi maksyma Berkeleya - esseestpercipi (istnieć to być postrzeganym) (Berkeley 2004:
98). Doświadczanie ciała w podwieszaniu opiera się również na jego perspektywie wizerunkowej, która warunkuje $\mathrm{w}$ pewnym zakresie odbieranie przyjemności. Przygotowując się do udziału w otwartym konwencie podwieszenia, badani mocno skupiają się na wyglądzie ciała, estetyzują je, by zapewnić sobie dobre samopoczucie cielesne płynące ze świadomości pozytywnego odbioru publiczności. Można tu nawet mówić wprost o sprzedaży wizerunku swojego podwieszonego ciała, wszak udział obserwatorów podczas takich pokazów jest zawsze odpłatny.

Podniecenie, wyrażane cieleśnie doznania i przeżycia osób podwieszanych stają się źródłem zmysłowej przyjemności, ekscytacji i radosnej euforii odczuwanej także przez tych, którzy są obserwatorami tej praktyki cielesnej. Mam tutaj na uwadze zarówno członków ekip technicznych, osoby oczekujące na udział $\mathrm{w}$ podwieszaniu, jak i biernych obserwatorów tworzących publiczność podczas otwartych konwencji podwieszania. O doświadczaniu w trakcie obserwacji praktyki podwieszania cudzej cielesności traktuje niniejsza wypowiedź:

Jak obserwowałem podwieszające się osoby, to ogarnęła mnie taka fascynacja, bo widziałem te różne emocje. Zobaczyłem, że ci ludzie świetnie się bawią, trochę jak na jakiejś dobrej imprezie. Wychodzi z nich miłość, radość. Cieszą się, że udało im się pokonać ból. Często jest przy osobie podwieszanej ktoś, kto ją kocha, płaczą razem, że mimo, że długo ta osoba się męczyła, to się udało. Widać te emocje. Słyszałem kiedyś taki po prostu iście orgiastyczny krzyk dziewczyny, która się podwieszała. Ja płonąłem wtedy sam. To było takie nagromadzenie emocji, że ja przyznam szczerze, że nie byłem nigdy w takim miejscu. Tyle emocji skumulowanych na takiej małej przestrzeni. To budzi moje emocje. W odróżnieniu od teatru, w którym wszystko jest wyreżyserowane, tutaj te emocje wynikały naturalnie. (M, 28 lat)

Podwieszanie ciała, mimo indywidualistycznego charakteru tej praktyki, nie jest pozbawione socjologicznego kontekstu, za brak którego Bryan S. Turner (1984: 54) potępia fenomenologiczne koncepcje ucieleśnienia. Ciało podwieszane jest również społecznie doświadczane. Relacje badanych potwierdzają, że w podwieszaniu to, co indywidualne, łączy się z tym, co społeczne. Przyjemne stany dostarczane tym, którzy są świadkami praktyki podwieszania, składają się na specyficzną atmosferę panującą podczas seansów podwieszania ${ }^{17}$. Georg Simmel (2006: 187), który twierdzi, że życie społeczne polega na doświadczaniu zmysłami innych ludzi, pisze: „Wrażenie zmysłowe, spowodowane widokiem innego człowieka, tonem jego głosu, wyczuwalną obecnością w tym samym pomieszczeniu, wywołuje uczucie przyjemności albo przykrości, wywyższenia

${ }^{17}$ Zdarza się, że wrażenia zmysłowe spowodowane widokiem kogos podwieszonego na hakach są zgola odmienne i zamias euforili ekscytacji wy wolują uczucie grozy, lęk, a nawet wstręt i obrzydzenie. Znamienny jest $w$ tym kontekscie obszerny opis rytuału "Tańca Słońca" u Mandanów, który sporzadził wspo$155,171)$ nazywany był przyjacielem Indian, nie ukrywajac doznanego w jego trakcie wstrzasu, tak oto rozpoczał swoja relację:,,OH! horribilevisu - et mirabiledictu! Chwała Bogu, że to, co widziałem już minęto, i że mogęo tym opowiedziećśswiatu". W dalszej jej częsci czytamy: „Niezachwiany hart ducha, z którym każdy z nich znosił tę część tortur, przechodzi wszelkie pojęcie; każ dy z nich, gdy nóż przechodził przez jego ciało, zachowywa niezmienny wyraz twarzy; a kilku z nich widząc mnie czyniacego szkice, kazali mi patrzec na ich twarze, na ktore pa-
trzyłem przez cały czas tego okrutnego działania, nie bedac w stanie wykryć niczego oprócz najmilszych uśmiechów, gdy patrzyli mi w oczy, gdy słyszałem, jak nóż rozcina ich ciało, czulem to niemal na sobie, a z moich oczu mimo woli płynęty po policzkach nie dające się powstrzymać łzy". 
albo poniżenia, podniecenia albo ukojenia”. „Nasze ciała i przyjemności - według Shustermana - są nam wspólne $\mathrm{w}$ równym stopniu, co nasze umysły i z pewnością nie są mniej publiczne niż nasze myśli. Przyjemność pojmuje się błędnie jako z istoty prywatną, dlatego, że niesłusznie utożsamia się ją z wewnętrznymi doznaniami cielesnymi, do których wyłączny dostęp ma odczuwająca je jednostka" (Shusterman 2016: 68). Michael Herzfeld przekonuje z kolei, że postrzeganie innych ludzi przez zmysły dalece wykracza poza sferę biologiczną. Analiza przykładów kulturowego uwarunkowania odczuwania zmysłowego pozwala na sformułowanie wniosku, że „odczuwanie cielesne i wartość kulturowa bezustannie wchodzą ze sobą w związki zależności" (Herzfeld 2004: 336). A zatem ciało podwieszane jawi się tutaj nie tylko jako element przedstawienia siebie, gry interakcyjnej i komunikacji, ale też jest ciałem wywołującym wrażenia.

Opisane powyżej doświadczenia z etapu podwieszania zwanego „lotem” czynią praktykę podwieszania niezwykle pożądaną i odgrywającą ważną rolę $\mathrm{w}$ świecie wewnętrznych przeżyć badanych, do których podwieszani chcą wracać. Co ważne, $\mathrm{w}$ żaden sposób badani nie utożsamiali swoich przeżyć z doznaniami o charakterze religijnym. Nie potrzebowali $w$ nich teologicznego oparcia. Zaliczają je jednoznacznie do tej kategorii doznań, które mają służyć ich rozwojowi osobistemu. Bezwzględnym warunkiem absorbowania tych przyjemnych doznań i wrażeń staje się jednak uprzednie pokonanie bólu, co jednak nie wszystkim podwieszanym się udaje. A zatem mamy tutaj do czynienia z tym rodzajem przyjemności, której osiągnięcie wiąże się z poczynieniem uprzednio określonego wysiłku. Badani byli w pełni świadomi tej istoty bólu, jego nieodzowności, tak w sensie pojawienia się, jak i konieczności zmierzenia się z nim. Nazywają go „dobrym bólem”, bo prowadzącym ostatecznie do pozytywnych przeżyć. Godząc się na przeżywanie cierpienia, przydają temu etapowi praktyki podwieszania charakteru ascetycznego, wpisując się w "neotradycjonalny trend" konsumowania ciała (Krajewski 1997: 20). „W swoim sprzeciwie wobec nowoczesnego relatywizmu i niestabilności, badani poszukują wartości nieredukowalnych, w czym pomóc ma im ból doświadczany $\mathrm{w}$ trakcie podwieszania oraz jego trwałe modyfikacje" (Kowal 2016: 95). Dlatego w zgromadzonym materiale empirycznym nie pojawiały się dane mogące świadczyć o tym, że osoby przystępujące do podwieszenia w jakikolwiek sposób próbują ten warunek ominąć, choćby na przykład poprzez przyjmowanie środków przeciwbólowych To właśnie dynamika bólu w pewnym sensie organizuje tę praktykę cielesną, wyznaczając jej kolejne etapy.

W obliczu zgromadzonego materiału empirycznego czuję się upoważniona do poczynienia konstatacji, że w praktyce podwieszania ciała najważniejszy jest właśnie lot, rozumiany jako oderwanie człowieka od ziemi. „Skoro ograniczeniem ciała jest to, że nie można go unieść do góry, w trakcie praktyki podwieszania $\mathrm{w}$ pewnym sensie zostaje ono pokonane"(Kowal 2016: 83). Jeśli zatem traktujemy podwieszanie ciała jako jedną z form jego modyfikacji, to należy ją rozumieć nie w kategoriach przekształcania wyglądu ciała, a jego funkcji. Naturalną pozycją ciała nie jest wszak jego zawieszenie w powietrzu.

\section{Wyjęcie haków i masaż ciała}

Kiedy wracają doznania bólowe, a ciało znów objawia się przede wszystkim jako byt materialny, który zaczyna stawiać opór ekspresji osoby podwieszanej rozumianej jako wysiłek „ja”, pojawia się decyzja o zakończeniu „latania na hakach”. Każda z podwieszanych osób sama decyduje o tym, kiedy ma być opuszczona na dół. Dotknięcie stopami podłoża według relacji badanych bezpowrotnie odcina dostęp do tych przeżyć i tej rzeczywistości, której doświadczyli, będąc podwieszonymi. To zejście na ziemię wydaje się mieć metaforyczny sens. Podobnie jak w wywyższeniu ciała, tak i w jego sprowadzeniu na ziemię nietrudno dostrzec symbolikę tego etapu podwieszania. Kiedy stan przyjemności obniża się, ciało zostaje opuszczane na dół:

Zakończyłem latanie wtedy, kiedy okazało sie, że ta pozycja podwieszenia przestała być już taka komfortowa, jak była na początku. (M, 28 lat)

Kiedy ciało zaczęło się tak dziwnie szarpać, nie poruszało się już tak bezwiednie i płynnie, to czułam, że ból wraca i że zaczyna zwyciężać. (K, 27 lat)

Opuszczenie ciała na dół jest bez wątpienia tym momentem, w którym badani wraz z poczuciem stałości odzyskiwali pełną kontrolę nad własną cielesnością, co jest przez nich utożsamiane z powrotem do materialnego ciała. Jednym z pierwszych doznań o charakterze fizycznym odczuwanych już po wyjęciu haków jest zdrętwienie miejsc na ciele, za które osoba została podwieszona. W przypadku wykonywania popularnej wśród badanych pozycji suicide drętwieją plecy i ręce. W siedzącej pozycji podwie- szenia zwanej lotus, która według badanych jest niezwykle „wygodną" pozycją i pozwala na długie, bo nawet kilkudziesięciominutowe podwieszenie, problemem fizycznego ciała są często występujące naderwania skóry w miejscach wbicia haków. Podobnie ma się rzecz $\mathrm{w}$ przypadku, gdy podwieszanie odbyło się przy zastosowaniu figur dynamicznych. Dopiero po wyjęciu haków osoba podwieszana dowiaduje się, że w trakcie lotu doszło do naderwania skóry, o czym sygnalizują pojawiające się charakterystyczne doznania bólowe.

Rola członków ekipy podwieszającej nie kończy się jednak z chwilą dotknięcia przez osobę podwieszaną stopami podłoża. Muszą oni jeszcze zaopiekować się jej ciałem. Po wyjęciu haków ze skóry, osoba podwieszana udaje się do odrębnego pomieszczenia, gdzie zostaje poddana bolesnemu masażowi ciała, a ściślej tych jego partii, w których były umiejscowione haki. Celem masażu ma być usunięcie nagromadzonego pod powłokami skórnymi powietrza, którego tym więcej dostaje do ciała, im więce wykorzystano do podwieszenia haków, im więcej ruchów w górze wykonała osoba podwieszana, wreszcie im dłużej trwało konkretne podwieszenie. Czynność masażu, wykonywana ze szczególną starannością, ma zapobiec zakażeniom miejsc przekłuć oraz kolejnym doznaniom bólowym mogącym pojawić się w ciągu kilku następnych dni po podwieszeniu:

Po wyjęciu haków jest kolejna nieprzyjemna dla mnie rzecz, czyli odpowietrzanie. U mnie, ze względu na to, że jestem bardzo chudy i mam niewiele tkanki tłuszczowej, która działa jak takie uszczelnienie, dostaje się tego powietrza dużo. Czeka mnie zawsze po 
podwieszeniu długi masaż, w którym po prostu wyciskają przez te otwory w skórze powietrze z całego ciała praktycznie. Bo nawet przy takim podwieszaniu na cztery haki, to powietrze miałem wszędzie - od dołu pleców, przez ramiona, aż po szyję. I to wyciskanie zawsze boli, ale robi się to po to, żeby nie było zakażenia i zakwasów. (M, 23 lata)

Na tym etapie znów do głosu dochodzi przede wszystkim fizyczność ciała. Rany muszą zostać zabezpieczone, a osoba podwieszana poinformowana o tym, jak powinna obchodzić się w ciągu najbliższych tygodni ze swoim ciałem. Podwieszanie ciała jest bowiem działaniem ryzykownym także $\mathrm{w}$ dalszej perspektywie czasowej. Przyjemność przeżyta w jego trakcie może mieć swoją cenę, którą są negatywne konsekwencje zdrowotne w postaci zakażeń ran i krwi. Dlatego miejsca gojących się popodwieszeniowych ran muszą być objęte szczególną troską, co oznacza konieczność utrzymywania ich w należytym stanie higienicznym oraz opatrunkową ochronę przez zanieczyszczeniami.

\section{Afterglow}

Termin afterglow w języku angielskim oznacza łunę, zorzę i poświatę, choć bywa też tłumaczony jako wspomnienie. Właściwie wszystkie te tłumaczenia można odnieść do tego, czego badani doświadczali w kolejnych dniach po seansie podwieszania. Echem tej praktyki cielesnej jest trwający od kilu dni do miesiąca stan opisywany jako doświadczanie utrzymującego się endorfinicznego nastroju oraz niespotykanego dotąd wyciszenia, w którym badani czuli się uwolnieni od napięć, nawet w sytuacjach wcześniej definiowanych jako trudne:
To uczucie euforii w moim przypadku po podwieszeniu nie znika. Ja pamiętam, że po swoim pierwszym podwieszeniu jeszcze przez tydzień chodziłam i tak sobie euforycznie popłakiwałam, tak ni stąd, ni zowąd. Te emocje gdzieś tam jeszcze we mnie siedziały. Pamiętam też, że wtedy mi się wszystko nagle takie błahe wydało. To doznanie dosyć długo miałam, zarówno po pierwszym, drugim, jak i trzecim podwieszeniu. To takie przyjemne rozedrganie, jakbym ciągle jeszcze wisiała, a nie stąpała po ziemi. Byłam dosyć długo takich jeszcze odmiennych lotów, trochę jakbym funkcjonowała poza rzeczywistością. (K, 28 lat)

Ten stan po to jest taka szczera radość. Świat jest piękniejszy, nic nie jest w stanie mnie zdenerwować i jakoś tak łatwiej się wszystko robi. To jest rodzaj takiej euforii. Ten stan takiego fajnego zadowolenia utrzymuje się u mnie jakieś dwa tygodnie. A potem znowu wszystko jest takie zwyczajne, choć już nie tak zwyczajne jak przed podwieszaniem. (K, 23 lata)

Jestem jeszcze ciągle parę centymetrów nad ziemią. Jestem bardzo wyluzowany, uspokojony, wiele rzeczy, którymi normalnie się przejmuję, wtedy jakoś robią się mniej ważne. (M, 28 lat)

Afterglow bierze się ze świadomości dokonania cielesnej transgresji, której wyznacznikiem ma być przekroczenie granicy bólu definiowanego jako słabośc czy ułomność ciała. To zatem przekroczenie natury ciała, które staje się możliwe w podwieszaniu jako działaniu sprzecznym z instynktownym podążaniem człowieka za przyjemnością. Podwieszenie ciała jest w ocenie badanych ich największym wyczynem cielesnym. Niewątpliwą korzyścią, jaką z niego czerpia, jest lepsze poznanie własnego cia- ła i przekonanie się o jego możliwościach. Poprzez udział w tej praktyce osoba podwieszana dowiaduje się, że jest w stanie przejść fizycznie przez podwieszanie, a także staje się bogatsza w wiedzę o tym, jak reaguje jej ciało w tej konkretnej sytuacji. Dlatego jeszcze przez kilka tygodni po podwieszeniu utrzymuje się u niej poczucie niebotycznej siły oraz większej władzy i kontroli nad własnym ciałem. O cielesnym wymiarze afterglow traktuja poniższe wypowiedzi:

Jest taka świadomość, że to zrobiłem. Jestem taki pobudzony i usatysfakcjonowany. I później w normalnym życiu, jak spotyka mnie jakaś sytuacja zagrożenia, trudna, wymagająca myślenia, jakaś ciężka sytuacja stresowa, to mam taką świadomość zawsze, że to zrobiłem, to co mi teraz może stanąć naprzeciw? Po samym podwieszeniu jeszcze długo trzyma jednak adrenalina. W tym stanie wiem, że mogę liczyć na moje ciało, znam je i wiem, że poradzi sobie z różnymi rzeczami. (...) W tym stanie byłem u dentysty, to było po moim drugim suspension. Boję się dentysty. Wykorzystałem technikę panowania nad bólem z podwieszania u dentysty. I faktycznie pomogło. A ja panicznie od dziecka bałem się dentysty. To był mój największy koszmar! (M, 23 lata)

Ten stan euforii dodatkowo wynika jeszcze z tego, że jak dałam radę się podwiesić na hakach, to już mogę tak naprawdę wszystko w życiu. Już nic mi nie jest straszne. Ja do tej pory tatuowałam się pod znieczuleniem, bo to było dla mnie tragiczne doświadczenie. Teraz wiem, że dam radę bez. Zdobyłam taką pewność związaną z bólem i to jest dla mnie kwestia najważniejsza. Jestem zdolna do nadludzkich rzeczy. To mi dało bardzo dużo pewności siebie. Bo to była walka z ciałem, ze sobą i wygrałam tę walkę. (K, 28 lat)

Jeśliby spojrzeć na podwieszanie ciała w kategoriach triumfu umysłu nad cielesnością, to dostrzegalny jest tutaj pewien paradoks. Oto słabsze, bo pokonane ciało w popodwieszeniowym stanie afterglow doświadczane jest jako lepsze, pod pewnymi względami doskonalsze, bo lepiej radzące sobie w określonych typach działania. Na płaszczyźnie samopoczucia cielesnego $\mathrm{w}$ stanie afterglow badani czują się wyzwoleni z ograniczeń ciała. Rzadko w tym stanie doświadczają dysfunkcji cielesnych rozumianych jako choroba czy jakiekolwiek niedomaganie ciała. Co ważne, stan ten nie zostaje zakłócony przez dolegliwości bólowe związane z procesem gojenia popodwieszeniowych ran. Jeśli chodzi o relację emocjonalną z własnym ciałem, to niektórzy z badanych przyznawali, że z każdą praktyką podwieszania bardziej lubią swoje ciało, ponieważ uznają je za bardziej funkcjonalne. Wiąże się to właśnie z lepszym poznaniem jego możliwości i tym samym pogłębieniem relacji ciało-umysł:

Czuję się przede wszystkim pewniej. I po prostu też lepiej czuję się z własnym ciałem, bo je zaakceptowałem bardziej dzięki podwieszaniu. W tym czasie tak czuję, że jest bliższa więź z ciałem, dlatego jest lepiej. Dużo wtedy jestem w stanie zrobić. Bardziej dynamicznie działam, bo jestem nakręcony tym wydarzeniem podwieszenia się na hakach. Przez jakiś czas jestem naładowany pewną energią, która mi pomaga w takim normalnym życiu. (M, 23 lata)

Sposób, w jaki badani doświadczają ciała w kolejnych dniach po podwieszeniu, określa też 
wyraźniejsze niż przed tą praktyką odczuwanie własnego ciała. Wspólne badanym było dobre samopoczucie cielesne, na które składało się poczucie lekkości ciała, nieskrepowanej wolności cielesnej i swoistego rodzaju otwartości ciała na nowe doświadczenia. Emile Durkheim (2010: 272), opisujący funkcje kultu negatywnego w obrzędach ascetycznych Australijczyków, tak oto pisze o skutkach cierpienia zadawanego ciału: „ból zwiększa energię życiową, powoduje wzrost włosów i brody, wzmacnia członki". Formułując zasadę, że „cierpienie generuje niezwykłą moc", przekonuje, że „W rzeczywistości (...) wielkość człowieka najwyraźniej się przejawia w sposób, w jaki stawia czoła cierpieniu". O samym cierpieniu pisze natomiast, że "słusznie uchodzi ono za sposób wiodący do wyzwolenia" (Durkheim 2010: 272).

Działający niezwykle silnie $\mathrm{w}$ „popodwieszeniowym" stanie afterglow mechanizm eskalacji kolejnych doznań i wrażeń cielesnych skłania badanych do poszukiwań możliwości ponownego podwieszenia. Mowa tutaj o przeżywanym na tym etapie „,swego rodzaju przymusie przystąpienia do kolejnych podwieszeń, który powstaje pod wpływem emocji i wrażeń doświadczanych nie tylko w trakcie samej praktyki, ale także na długo po jej zakończeniu" (Kowal 2016: 91). Podjęcie takich prób nie jest jednak natychmiast możliwe. Cielesnym warunkiem przystąpienia do podwieszenia jest wszak wygojenie się miejsc, w których naruszona została ciągłość tkanki skórnej. Nawet jednak całkowita regeneracja skórna tych miejsc nie oznacza możliwości ponownego za nie podwieszenia. $\mathrm{W}$ miarę kolejnych podwieszeń na mapie ciała osoby praktykującej tę formę zabawy z ciałem pojawiają się tak zwane "miejsca zużyte", które muszą być pomijane podczas aplikowania haków w następnych podwieszeniach.

\section{Blizny na ciele}

Podwieszanie ciała pozostawia widoczne znaki. Stanowią o nich około półcentymetrowe blizny, które są śladami po wbiciu w ciało haków ${ }^{18}$. Nie mają one jednak charakteru trwałego. Zwykle po około dwóch latach od seansu podwieszania prawie całkowicie znika po nich ślad. Jak wynika $\mathrm{z}$ analiz zgromadzonego materiału empirycznego, badan nie mają głęboko spersonalizowanego stosunku do popodwieszeniowych blizn. Traktują je jako naturalną konsekwencję podjętych wobec ciała wyborów. Pogodzenie się z ich obecnością uznają natomiast za przejaw odpowiedzialności za wszystkie te działania, które w podwieszaniu są skierowane na ciało:

Niby podwieszanie jest bardziej drastyczne, ale, szczerze mówiąc, gorzej goją się kolczyki niż rany po podwieszeniu. Bo jednak przy kolczyku coś tam w tej ranie jest i cały czas ją podrażnia. A po wyjęciu haka to są malutkie ranki. (M, 23 lata)

Nie przeżywam tych blizn, traktuję je jako dodatek skutek uboczny podwieszania. Po prostu są. One sa bardzo małej wielkości. Wyglądają jak małe pryszcze. $Z$ upływem czasu muszę się naprawdę postarać, żeby je znaleźć. (K, 27 lat)

W swoich analizach starałam się dociec, jaką spełniają funkcję. Nie przypisując bliznom żadnego szczególnego znaczenia związanego z ich potencjalną symboliką, niektórzy uznają je co najwyżej za osobistą pamiątkę tego wydarzenia, jakim było podwieszanie. Dla tych badanych to pewnego rodzaju przypomnienie o swoim cielesnym wyczynie, a zarazem znak rozpoznawczy dla tych, którzy również dostąpili tej praktyki. Przez osoby, które nigdy nie zetknęły się z tematem podwieszania ciała, są natomiast najczęściej niedostrzegane. Zresztą większość blizn przykryta jest najczęściej ubraniem:

Patrząc na te blizny, przypominam sobie, co zrobiłem. Na każdą bliznę jak patrzę, to przypominam sobie to konkretne podwieszenie. Ja swoje blizny strasznie lubię. Wracają te emocje związane z podwieszaniem. To są same pozytywne rzeczy. Dla mnie blizny to taka pamiątka. I dla mnie są wyjątkowe. (M, 23 lata)

Ktoś, kto się nie podwieszał ani nie był blisko tego, to się nie zorientuje w ogóle, że to są blizny. Ale ktoś, kto się na tym zna, dostrzeże, że są w linii prostej, że one się nie biorą znikąd. (K, 27 lat)

Blizny pozostają szczególnie „użyteczne” wtedy, kiedy kończy się stan afterglow. Zapisane na karcie historii ciała wywołuja wspomnienia, przypominają o tym doświadczeniu cielesnym, a zwłaszcza o tych doznaniach, które udało się badanym przeżyć w fazie lotu. Ale obecność blizn okazuje się też problemem estetycznym, który przeszkadza w realizacji planów badanych osób noszących się z zamiarem udziału w otwartym konwencie podwieszania:

Niektórzy mają tak, że podwieszą się raz i koniec, więcej nie chcą. A ja należę do tej drugiej grupy, że chcę więcej i już teraz czuję, że znowu chcę. I tak na- prawdę jedyna przeszkoda, jaką czuję $\mathrm{w}$ tej chwili, to są blizny. U mnie one są spore i niezbyt ładne. One zdecydowanie mnie szpecą. Całe plecy mam $\mathrm{w}$ takie kropeczki. I to jest przeszkoda, żeby się podwiesić. Bo one są zagojone, ale są po prostu brzydkie. Ciągle je jeszcze widać. W ogóle będę teraz wymyślać takie pozycje, gdzie blizn nie będzie bardzo widać. (K, 23 lata)

Dla cytowanej wyżej badanej blizny pozostają cielesnym stygmatem, który niezaprzeczalnie oszpeca ciało. Kwestie estetyki ciała po podwieszeniu nie sa jednak uwzględniane w decyzji badanych o udziale $\mathrm{w}$ tej praktyce cielesnej. O ile obecność blizn jest uznana za jeden z kosztów podwieszania, to w przeprowadzonym bilansie zysków i strat badani uznają, że znacznie przewyższają je osiągnięte dzięki podwieszeniu korzyści.

\section{Podsumowanie}

Poznanie sposobu, w jaki badani doświadczaja swojego ciała w trakcie podwieszania, pozwala na zdefiniowanie sensu tej praktyki. $Z$ analizy zgromadzonego materiału empirycznego wynika, że każdorazowy udział w podwieszaniu jest personalnym doświadczeniem dla każdego z badanych. Choć jego sens określany jest zarówno jako poznawczy, duchowy, jak i artystyczny, ciało w podwieszaniu doświadczane jest przede wszystkim jako źródło cierpienia i przyjemności.

Ascetyczny wymiar przeżyć badanych staje się częścią ich pracy nad ciałem i stwarzanymi przez nie ograniczeniami. Wielu traktowało tę praktykę jako swego rodzaju test czy sprawdzian ciała. O ile w inicjacyjnym podwieszaniu badani dowiadywali się o 
progu własnej wytrzymałości bólowej, to już w kolejnych tego rodzaju praktykach wykorzystywali tę wiedzę do pracy nad ciałem i pogłębiania jego relacji z umysłem. $\mathrm{W}$ rezultacie wiedza o własnym ciele stopniowo wzrasta, przez co badani nabywają przekonania, że ciało jest całkowicie poznawalnym obiektem. Co ważne, odczucia bólowe nie słabną przy próbach kolejnych podwieszeń. Ilość doświadczeń związanych z tą praktyką nie zmniejsza ani doznań bólowych związanych z wykonywaniem przekłuć, ani samym podwieszeniem. Ból jawi się jako stały element procesu, jaki osoba podwieszana jest zmuszona przejść. Bólu nie da się też jednoznacznie oddzielić od przyjemności afektywnej, bo nawet przy jej najintensywniejszym doświadczaniu ból całkiem nie znika, tak jak nie znika świadomość ciała, która zachowana zostaje poprzez przeżywanie sensoryczno-zmysłowych doświadczeń.

Przyjemnościowy aspekt doznań jest najsilniej zaznaczony $\mathrm{w}$ doświadczaniu własnego ciała przez osoby podwieszane. Pozostaje jednak odpowiedzieć na pytanie, czy doznawana w podwieszaniu przyjemność jest celem samym w sobie przystępujących do tej praktyki cielesnej. Jeśliby połączyć ze sobą treści dotyczące motywów podwieszania z tymi, które traktują o ich przeżyciach $\mathrm{w}$ trakcie trwania tej praktyki, to okaże się, że przyjemność nie jest celem, a środkiem badanych do tego, co nazywają „rozwojem osobistym”, „samorealizacją", „samodoskonaleniem” czy „przemianą”. Jeśli doświadczenie tej przyjemności jest wystarczająco silne dla osoby podwieszanej, dochodzi do czegoś, co można nazwać naznaczeniem , ja”. Pozostawiony przez przeżytą przyjemność głęboki ślad ma zmieniać badanych, nie tylko wzmacniając ich ciała, ale też przewartościowując ich potrzeby i pragnienia czy wytyczając nowe cele w życiu.

Ciało w trakcie praktyki podwieszania doświadczane jest zarówno jako byt obiektywny, jak i subiektywny. Znaczna część przeżyć badanych dotyczy jego biologicznych i fizycznych aspektów. Najpierw doznania mają wyłącznie cielesny charakter i wiążą się z doświadczaniem ciała głównie jako bytu materialnego. To tak, jakby najpierw podwieszone zostało wyłącznie ciało. $W$ relacjach badanych odnoszących się zwłaszcza do początkowych aktów podwieszania daje się dostrzec wyraźny kartezjański dualizm, podkreślaną silnie odrębność ciała od umysłu. Ale to traktowane w wyraźnie instrumentalny sposób ciało zostaje pokonane przez umysł, wysiłkiem którego udaje się przezwyciężyć ból $\mathrm{Z}$ drugiej zatem strony widoczny jest w tym doświadczeniu silny związek ciała i umysłu, których pełne rozdzielnie, jak pokazują przeżycia badanych ze szczytowego momentu tej praktyki, nie jest do końca możliwe. Mimo wyraźnie duchowego charakteru przeżyć na tym etapie podwieszania, świadomość ciała zostaje zachowana. Nie jest zatem tak, że po tym, jak podwieszone zostaje ciało, przychodzi czas na „podwieszenie umysłu”. Byty te w swojej wzajemnej niezbędności pozostają wszak nierozłączne. Ciało wchodzi w relację z , ja”, wyraźnie ją zacieśniając. Całość poznanych przeżyć i doznan badanych na wszystkich etapach tej praktyki upoważnia mnie do poczynienia konstatacji o nierozdzielności ciała i ,ja” przy równoczesnym „chwilowym” byciu ciała poza ,ja", co następuje wtedy, kiedy doświadczane jest ono przede wszystkim jako byt materialny. Ale mimo, że „ja” czasami pozostaje w owym luźnym związku z ciałem, podczas podwieszenia nie dochodzi nigdy do jego całkowitego oddzielenia od ciała. Wrażenie wspomnianego dualizmu bierze się z interpretacji doświadczania podwieszanego ciała $\mathrm{w}$ konkretnym momencie tej praktyki. Jeśliby spojrzeć na podwieszanie już dokonane w sposób linearny, ciało i umysł pozostają ze sobą w stałej współpracy i stanowią całościowy i spójny konstrukt. Podwieszanie jawi się zatem jako forma ekspresji siebie w rozumieniu jedności ciała i umysłu. Jest nie tylko potrzebne do budowania i rozwijania koncepcji siebie, ale wręcz ją determinuje. Sposób, w jaki badani odnoszą się do swojej cielesności, pozwala na sformułowanie tezy, że wszystkie kierowane na ich ciała praktyki stają się źródłem tożsamości tych osób. Chodzi tutaj o nadawanie sensu cielesnemu doświadczaniu rzeczywistości przez badanych. Podkreślając tu mocno indywidualistyczny charakter podwieszania ciała, warto raz jeszcze zaznaczyć, że jego praktykowanie

\section{Bibliografia}

Ambrosia Kristine, Lanza Joseph (1990) Fakir Musafar Interview [w:] Adam Parfrey, ed., Apocalypse Culture. Los Angeles: Feral House, s. 106-117.

Atkinson Michael, Young Kevin (2001) Flesh Journeys: Neo Primitives and the Contemporary Rediscovery of Radical Body Modification. „Deviant Behavior: An Interdisciplinary Journal”, vol. 22, no. 2, s. 117-146.

Bauman Zygmunt (1995) Ciało i przemoc w obliczu ponowoczesności. Toruń: Wydawnictwo Uniwersytetu Mikołaja Kopernika.

Baumeister Roy T. (1988) Masochism as Escape from Self. .The Journal of Sex Research", vol. 25, no. 1, s. 28-59. podporządkowane jest przede wszystkim tożsamościowym poszukiwaniom badanych. O marginalnym znaczeniu pozostaje natomiast dla badanych społeczny aspekt podwieszania. Udział w podwieszaniu nie służy wyrażaniu tożsamości grupowej. Współczesne podwieszanie ciała, w odróżnieniu od sensu jego pierwotnych form, ma służyć przede wszystkim jednostce.

Reasumując, doświadczanie własnej cielesności przez osoby praktykujące podwieszanie ciała jest $\mathrm{w}$ istocie doświadczaniem dosłownie i metaforycznie stanu zawieszenia między ziemią a niebem. To stan pomiędzy doświadczaniem materialności ciała wraz ze wszystkimi jego ograniczeniami i słabościami, z jakimi mamy do czynienia na ziemi, a ponadcielesnym doświadczaniem ciała, które wywołuje uniesienie, zachwyt, euforię i błogość kojarzoną $\mathrm{z}$ niebem. 
Charmaz Kathy (2009) Teoria ugruntowana. Praktyczny przewodnik po analizie jakościowej. Przełożyła Barbara Komorowska. Warszawa: Wydawnictwo Naukowe PWN

Ciężki Jakub (2006) Ciato jako obiekt operacij artystycznej. Dostępny w Internecie ‘www.miki.hg.pl/pra_zjawisko.phps [dostęp 15.03.2016 r.

Crossley Nick (1995) Merleau-Ponty, the Elusive Body and Carnal Sociology. „Body and Society”, vol. 1, no. 1, s. 43-66.

Cyrus Irene Salome (1997) Indianie Ameryki Pótnocnej. Przełożył Ryszard Woinakowski. Kraków: Wydawnictwo Znak.

Durkheim Émile (2010) Elementarne formy życia religijnego. System totemiczny wo Australii. Przełożyła Anna Zadrożyńska. Warszawa: Wydawnictwo Naukowe PWN.

Eliade Mircea (1997) Inicjacja, obrzędy, stowarzyszenia tajemne. Narodziny mistyczne. Przełożył Krzysztof Kocjan. Kraków: Wydawnictwo Znak.

Foucault Michel (2000) Filozofia, historia, polityka. Wybór pism. Przełożyli Damian Leszczyński, Lotar Rasiński. Warszawa, Wrocław: Wydawnictwo Naukowe PWN.

Frank Arthur W. (1991) For a Sociology of the Body: an Analytical Review[w:] Mike Featherstone, Mike Hepworth, Bryan S. Turner, eds., The Body. Social Process and CulturalTheory. London, Thousand Oaks, New Delhi: Sage Publications, s. 36-102.

Gąssowski Jerzy (1996) Indianie Ameryki Pótnocnej od poczatków po wiek XIX. Warszawa:Wyższa Szkoła Humanistyczna w Pułtusku i Wydawnictwo Trio

Glaser Barney G., Strauss Anselm L. (2009) Odkrywanie teorii ugruntowanej. Strategie badania jakościowego. Przełożył Marek Gorzko. Kraków:Zakład Wydawniczy Nomos.

Goffman Erving (2011) Relacje w przestrzeni publicznej. Mikrostudia porzadku publicznego. Przełożyła Olga Siara. Warszawa: Wydawnictwo Naukowe PWN.

Herzfeld Michael (2004) Antropologia. Praktykowanie teorii w kulturze i społeczeństwie. Przełożyła Maria M. Piechaczek. Kraków: Wydawnictwo Uniwersytetu Jagiellońskiego.
Husserl Edmund (1974) Idee czystej fenomenologii i fenomenologicznej filozofii. Ksiegga druga. Przełożyła Danuta Gierulanka. Warszawa: Państwowe Wydawnictwo Naukowe.

Husserl Edmund (1982) Medytacje kartezjańskie z dodaniem uwaag krytycznych Romana Ingardena. Przełożył Andrzej Wajs. Warszawa: Państwowe Wydawnictwo Naukowe.

Klesse Christian (2000) 'Modern Primitivism': Non-Mainstrean Body Modification and Racialized Representation [w:] Mike Featherstone, ed., Body Modification. London, Thousand Oaks, New Delhi: Sage Publications, s. 15-38.

Konecki Krzysztof T. (2000) Studia z metodologii badań jakościowych. Teoria ugruntowana. Warszawa: Wydawnictwo Naukowe PWN.

Kowal Katarzyna (2016) W poszukiwaniu siebie. Indywidualn motywy podwieszania ciata praktykowanego wspótcześnie w Polsce. „Studia Humanistyczne AGH”, t. 15, nr 4, s. 73-99.

Krajewski Marek (1997) Konsumpcja i wspótczesność. O pewne perspektywie rozumienia świata społecznego. „Kultura i Społeczeństwo", t. 41, nr 3, s. 3-24.

Leder Drew (1990) The Absent Body. Chicago: University of Chicago Press.

Maika-Rostek Dorota (2010) Ekstremalne modyfikacie ciata [w:] Ewa Banaszak, Paweł Czajkowski, red., Corpus delicti rozkoszne ciało. Szkice nie tylko z socjologii ciała. Warszawa: Wydział Nauk Społecznych Uniwersytetu Wroclawskiego i Wydawnictwo Difin, s. 105-121.

Maslow Abraham H. (1986) W stronę psychologii istnienia. Przełożyła Irena Wyrzykowska. Warszawa: Instytut Wydawniczy PAX.

Merleau-Ponty Maurice (1996) Widzialne i niewidzialne. Przełożyli Małgorzata Kowalska, Jacek Migasiński, Renata Lis, Iwona Lorenc. Warszawa: Fundacja Aletheia.

Merleau-Ponty Maurice (2001) Fenomenologia percepcii. Przełożyli Małgorzata Kowalska, Jacek Migasiński. Warszawa: Fundacja Aletheia.

Métraux Alfred (1943) A Myth of the Chamacoco Indians and Its Social Si-
Musafar Fakir (1990) Body Play [w:] Adam Parfrey, ed., Apocalypse Culture. Los Angeles: Feral House, s. 104-105.

Myers James (1992) Nonmainstream Body Modification: Genital Piercing, Branding, Burning, and Cutting. ,Journal of Contemporary Ethnography", vol. 21, no. 3, s. 276-306.

Posern-Zielińska Mirosława, Posern-Zieliński Aleksander (1977) Indiańskie wierzenia i rytuaty. Wrocław, Warszawa, Kraków, Gdańsk: Zakład Narodowy im. Ossolińskich.

Shilling Chris (2010) Socjologia ciała. Przełożyła Marta Skowrońska. Warszawa: Wydawnictwo Naukowe PWN.

Shusterman Richard (2016) Świadomość ciała. Dociekania z zakresu somaestetyki. Przełożyli Wojciech Małecki, Sebastian
Stankiewicz. Kraków: Towarzystwo Autorów i Wydawców Prac Naukowych Universitas.

Simmel Georg (2006) Most i drzwi. Wybór esejów. Przełożył Małgorzata Łukasiewicz. Warszawa: Oficyna Naukowa.

Teplicki Zbigniew (1994) Wielcy Indianie Ameryki Pótnocnej. Warszawa: Wydawnictwo Książka i Wiedza.

Turner Bryan S. (1984) The Body and Society. Oxford: Basil Blackwell.

Turner Bryan S. (1992) Regulating Bodies. Essays in Medical Sociology. London: Routledge.

Vale V., Juno Andrea (1989) Modern Primitives: An Investigation of Contemporary Adornment and Ritual. San Francisco: RE/Search.

\section{Cytowanie}

Kowal Katarzyna (2018) Między ziemia a niebem... Doświadczanie własnej cielesności przez osoby praktykujace podwieszanie ciała studium socjologiczne. „Przegląd Socjologii Jakościowej”, t. 14, nr 2, s. $84-119$ [dostęp dzień, miesiąc, rok]. Dostępny w Internecie: ‘www.przegladsocjologiijakosciowej.org?. DOI: http://dx.doi.org/10.18778/1733-8069.14.2.04.

\section{Between Earth and Sky...Experience of Own Corporeality by People Practicing Body} Suspension-Sociological Study

Abstract: The aim of the paper is to analyze the experience of the body of a person suspended by the skin from hooks, adoptin the perspective of the subject as an embodied entity. The empirical basis for the paper is the author's own sociological research conducted in the group of 30 people practicing body suspension, the selection of whom had the character of purposive sampling, determined by at least two-time participation in this corporeal practice. Gathering and analyzing of the research material were subordinated to the procedures of grounded theory methodology, within the framework of which the technique of free-form guided interview was used. As the practice of body suspension takes place according to the specific order, the analysis of the empirical material has the form of discussion of the body experience at its six consecutive stages, four of which are strictly related to the act of body suspension itself, while the last two refer to body experience after the act of body suspension. In the practice of body suspension by the skin from hooks, the human body is experienced primarily as a source of pleasure, the achievement of which is determined by the prior experience of the body as a source of pain. Pain is an indispensable sensation here because it determines the dynamics of this corporeal practice. The suspended body is also regarded as an object of ownership, controlled by the subjects to a different extent, as a place of contact with one's own "ego," a tool of expression and communication, and, finally, as an object of aesthetic and hygienic care. In the analysis of the suspended body experience, consideration was given to the phenomenological perspective where the body is treated as a physical object, which is a body alive, sensitive, and emotional.

Keywords: body, corporeality, own body experience, phenomenology, body suspension, body modifications 